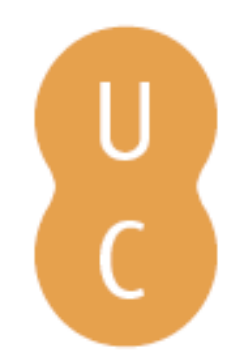

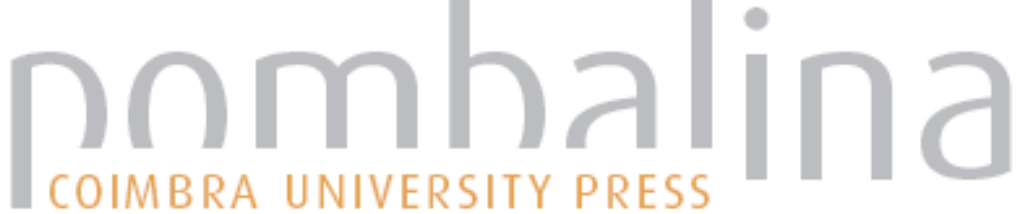

\section{Formação de adjetivos}

Autor(es): $\quad$ Rio-Torto, Graça; Rodrigues, Alexandra Soares

Publicado por: Imprensa da Universidade de Coimbra

URL

persistente: URI:http://hdl.handle.net/10316.2/38915

DOI: $\quad$ DOI:http://dx.doi.org/10.14195/978-989-26-0864-8_3

Accessed : $\quad$ 26-Apr-2023 15:21:56

A navegação consulta e descarregamento dos títulos inseridos nas Bibliotecas Digitais UC Digitalis, UC Pombalina e UC Impactum, pressupõem a aceitação plena e sem reservas dos Termos e Condições de Uso destas Bibliotecas Digitais, disponíveis em https://digitalis.uc.pt/pt-pt/termos.

Conforme exposto nos referidos Termos e Condições de Uso, o descarregamento de títulos de acesso restrito requer uma licença válida de autorização devendo o utilizador aceder ao(s) documento(s) a partir de um endereço de IP da instituição detentora da supramencionada licença.

Ao utilizador é apenas permitido o descarregamento para uso pessoal, pelo que o emprego do(s) título(s) descarregado(s) para outro fim, designadamente comercial, carece de autorização do respetivo autor ou editor da obra.

Na medida em que todas as obras da UC Digitalis se encontram protegidas pelo Código do Direito de Autor e Direitos Conexos e demais legislação aplicável, toda a cópia, parcial ou total, deste documento, nos casos em que é legalmente admitida, deverá conter ou fazer-se acompanhar por este aviso.

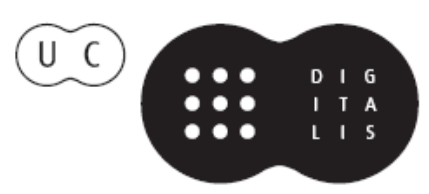




\section{GRAMÁTICA \\ DERIVACIONAL \\ DO PORTUGUÊS}

GRAÇA RIO-TORTO

ALEXANDRA SOARES RODRIGUES

ISABEL PEREIRA

RUI PEREIRA

SÍLVIA RIBEIRO

2. ${ }^{a}$ EDIÇÃO

IMPRENSA DA UNIVERSIDADE DE COIMBRA COIMBRA UNIVERSITY PRESS 


\section{CAPÍTULO 3. FORMAÇÃO DE ADJETIVOS}

Graça Rio-Torto

Alexandra Soares Rodrigues 35

Este capítulo é dedicado à formação de adjetivos denominais (3.1.), denumerais (3.2.) e deverbais (3.3.).

Os adjetivos denominais e denumerais formados por sufixação têm por base um radical. Os adjetivos deverbais formam-se através da combinação do sufixo a um tema verbal. Excetuam-se os adjetivos deverbais sufixados em -ão, que têm por base um radical verbal ${ }^{36}$. Para além da sufixação, a formação de adjetivos recorre também ao mecanismo da conversão (cf. secções 3.3.19 e 3.3.20 deste cap.).

Sendo o adjetivo "uma classe de palavras de natureza essencialmente gregária, adjuntiva, no sentido em que tem de estar associado a um Nome ou a um Verbo, no caso necessariamente predicativo" (Rio-Torto 2006: 104), a semântica dum adjetivo denominal ou deverbal tem em conta não apenas a semântica da base que nele se encontra incorporada, como também a do Nome que o adjetivo modifica.

35 Alexandra Soares Rodrigues é autora da secção 3.3 Adjetivos deverbais. As demais secções são da autoria de Graça Rio-Torto.

36 Os adjetivos deadjetivais avaliativos (bonitão: bonit-RadA ão; limpinho: limpRadA + inho; tristonho: trist-RadA + onho) e z-avaliativos (levezinho/a: leve+zinh-) são descritos no capítulo 5 . 


\subsection{Adjetivos denominais: bases, sufixos, produtos}

Os adjetivos denominais derivados por sufixação são conhecidos por "adjetivos de relação" por duas ordens de razões:

(i) pelo facto de estabelecerem com as suas bases uma conexão semântica genericamente parafraseável por 'que está relacionado com $\mathrm{x}$ ', 'que é relativo a $\mathrm{x}$ ', em que $\mathrm{x}$ representa o que a base denota: alfandegário 'relativo a alfândega', comercial 'que está relacionado com o comércio'; mineira [atividade, indústria] 'que está relacionado com as minas';

(ii) pelo facto de, na sua qualidade de adjetivos, predicarem aquilo que o nome a que se associam denota e de, portanto, estabelecerem também uma conexão semântica com o $\mathrm{N}$ do grupo nominal em que se inserem.

A semântica dum adjetivo denominal reflete, necessariamente, a semântica da sua base, mas também as idiossincrasias semânticas do sufixo ativado. Os adjetivos penal e penoso, ambos construídos com base no radical nominal pen-, de pena, denotam 'relativo a pena' e 'que comporta pena' (cf. direito penal vs. decisão penosa); o mesmo se aplica a carnal e carnudo, que significam, respetivamente, 'que diz respeito à carne, por oposição ao espírito' e 'que tem carne/polpa (em fruto) consistente, carnoso'.

Do mesmo modo, pode haver variação no semantismo do adjetivo em função do $\mathrm{N}$ que este modifica: em jóia familiar o adjetivo equivale a 'da família', em que esta é a possuidora, e em ambiente familiar o adjetivo equivale a 'típico de família, acolhedor e/ou conhecido'.

No quadro que se segue apresentam-se alguns sufixos com os quais se derivam adjetivos denominais e respetivos produtos. Uma vez que o número dos sufixos adjetivalizadores denominais ascen- 
de a mais de quarenta (cf. Quadro 6, em 3.1.3.7. deste capítulo), mencionamos apenas alguns dos mais representativos do português:

\begin{tabular}{|c|c|}
\hline Sufixo & Adjetivos \\
\hline -áce- & $\begin{array}{l}\text { amiantáceo, azuláceo, bacteriáceo, campanuláceo, coralináceo, cornáceo, } \\
\text { coroláceo, fareláceo, fermentáceo, larváceo, magnoliáceo, sebáceo, tulipáceo, } \\
\text { turbináceo, welwitschiáceo }\end{array}$ \\
\hline$-a d-$ & azulado, frutado, iodado, mentolado, salmonado \\
\hline$-a l$ & $\begin{array}{l}\text { acidental, carnal, dental, imperial, mortal, normal, sentimental, teatral, } \\
\text { trimestral }\end{array}$ \\
\hline$-a n-$ & açoreano, africano, paulistano, pessoano, serrano, tijucano \\
\hline$-a r$ & clientelar, exemplar, familiar, lapidar, medular, plantar \\
\hline -ári- & dentário, lendário, mamário, panfletário, partidário, rodoviário \\
\hline$-e-$ & bercúleo, purpúreo, térreo \\
\hline -eir- & aventureiro, caloteiro, certeiro, interesseiro, traiçoeiro \\
\hline -ense & almadense, berlinense, ovarense, sintrense, timorense, viseense \\
\hline -ent- & barrento, bolorento, calorento, ciumento, peçonbento, sum(ar)ento \\
\hline -esc- & animalesco, cavalheiresco, dantesco, folhetinesco, livresco, simiesco \\
\hline -ês & burgûes, chinês, cortês, francês, montanhês, pedrês \\
\hline$-i c-$ & $\begin{array}{l}\text { artístico, calórico, diabético, granítico, metódico, melancólico, metálico, } \\
\text { tsunâmico }\end{array}$ \\
\hline -in- & andino, cristalino, manuelino, pombalino, purpurino, vicentino, uterino \\
\hline -ista & autista, bombista, budista, carteirista, cubista, grecista, miguelista \\
\hline -oide & animaloide, cameloide, esferoide, espiraloide, bumanoide, ovoide \\
\hline -os- & $\begin{array}{l}\text { amoroso, chuvoso, esplendoroso, estiloso, gelatinoso, melindroso, mentiroso, } \\
\text { pantanoso, venenoso, ventoso }\end{array}$ \\
\hline$-u d-$ & barrigudo, cabeludo, carnudo, peludo, sisudo, sortudo, trombudo \\
\hline
\end{tabular}

Quadro III.1. Sufixos formadores de adjetivos denominais

A alguns adjetivos denominais (cf. os povos africanos, uma água cristalina, o doente diabético, o pulmão folhoso, o portal manuelino) correspondem nomes que possuem a mesma base (cf. os africanos jovens, ter o cristalino opacificado, um diabético imobilizado, o folhoso dos ruminantes, o manuelino escalabitano). Neste capítulo são apenas tidos em conta os adjetivos.

Em 3.1.1. caraterizam-se os radicais nominais que estão na base dos adjetivos denominais e descrevem-se algumas das propriedades combinatórias das bases e dos sufixos adjetivalizadores. Em 3.1.2. descrevem-se os valores semânticos dos sufixos e dos produtos derivados. 


\subsubsection{Condições de combinatória entre bases e sufixos}

Os sufixos que formam adjetivos denominais combinam-se com radicais morfologicamente simples, com radicais morfologicamente complexos (ginasta/ginástico, auxílio/auxiliar), sejam derivados ou compostos, pelo que não há correlações impositivas entre a estrutura morfológica da base e o sufixo adjetivalizador usado.

\begin{tabular}{|c|c|c|c|}
\hline Sufixo & Bases simples & Bases derivadas & Bases compostas \\
\hline$-a l$ & carnal, epocal & centesimal, empresarial & autoestradal, poligonal \\
\hline -an- & craniano & paulistano & microbiano \\
\hline$-a r$ & anelar, bospitalar & celular, milenar & triangular, intervalar \\
\hline -ári- & lendário, mamário & centenário, partidário & $\begin{array}{l}\text { aeroportuário, ferroviário, } \\
\text { rodoviário }\end{array}$ \\
\hline eir- & certeiro & borralbeiro & bancarroteiro \\
\hline$-e n b-$ & açorenbo, ferrenbo & ferreirenbo & $\begin{array}{l}\text { costarriquenbo, } \\
\text { portorriquenbo }\end{array}$ \\
\hline -ens- & $\begin{array}{l}\text { madeirense, } \\
\text { ovarense }\end{array}$ & $\begin{array}{l}\text { chamusquense } \\
\text { ferreirense, matosinbense }\end{array}$ & $\begin{array}{l}\text { copacabanense, } \\
\text { crucilandense } \\
\text { matogrossense, uberlandense }\end{array}$ \\
\hline -ent- & $\begin{array}{l}\text { bolorento, } \\
\text { calorento }\end{array}$ & $\begin{array}{l}\text { lamacento, olbeirento } \\
\text { ternurento }\end{array}$ & colibacilento, sarrabulbento \\
\hline$-i c-$ & fílmico, pélvico & artístico, periodístico & ortográfico, radiológico \\
\hline -ista & clubista, portista & materialista, sanitarista & $\begin{array}{l}\text { automobilista, manobrista, } \\
\text { terceiromundista }\end{array}$ \\
\hline$-o s-$ & nervoso, rigoroso & $\begin{array}{l}\text { condimentoso, } \\
\text { membranoso }\end{array}$ & espalhafatoso, sarrabulboso \\
\hline$-u d-$ & cabeludo, sortudo & faceirudo, ramalbudo & pernaltudo, sobrancelbudo \\
\hline
\end{tabular}

Quadro III.2. Adjetivos denominais formados a partir de bases simples e complexas

Alguns sufixos têm a possibilidade de se combinar com bases derivadas elas mesmas portadoras de sufixos vários. Como se observa no quadro III.3, os adjetivos denominais em -ic- podem ter por base radicais ${ }^{37}$ sufixados em -at $(o)$, -en $(o),-i(o),-i s t(a),-i t(a)$,

37 Este sufixo, como muitos outros, também se acopla, ainda que em menor escala, a adjetivos (cf. entusiasta/entusiástico). 
-it(e), -it(o), destacando-se os sufixados em -ist(a), por este ser um operador muito disponível e produtivo na atualidade.

\begin{tabular}{|c|c|c|}
\hline Sufixo & Base: radical sufixado de & Derivado em -ic- \\
\hline -ato & mecenato & mecenático \\
\hline -eno & nafteno & nafténico \\
\hline$-i o$ & urânio; volfrâmio & urânico; volfrâmico \\
\hline$-i s t a$ & $\begin{array}{l}\text { africanista; diarista; dicionarista; } \\
\text { galerista; bispanista; jornalista; } \\
\text { montanbista; mutualista; } \\
\text { nacionalista; partidarista; ritualista; } \\
\text { seminarista; tenista; urbanista; } \\
\text { violinista }\end{array}$ & $\begin{array}{l}\text { africanístico; diarístico; } \\
\text { dicionarístico; galerístico; } \\
\text { bispanístico; jornalístico; } \\
\text { montanbístico; mutualístico; } \\
\text { nacionalístico; partidarístico; } \\
\text { ritualístico; seminarístico; tenístico; } \\
\text { urbanístico; violinístico }\end{array}$ \\
\hline$-i t a$ & islamita; jesuíta & islamítico; jesuítico \\
\hline -ite & ferrite; magnesite; octaedrite & ferrítico; magnesítico; octaedrítico \\
\hline -ito & meteorito; quartzito & meteorítico; quartzítico \\
\hline
\end{tabular}

Quadro III.3. Bases sufixadas e respectivos adjetivos derivados em -ic-

Também não existem condições impositivas de natureza semântica que regulem a adjunção de um sufixo adjetivalizador à sua base. Frequentemente um mesmo sufixo pode combinar-se com bases de significação muito variada. Assim acontece com -ic-. No Quadro III.5 dão-se exemplos de adjunção deste sufixo a bases que denotam matérias/substâncias, objetos/artefactos, partes do corpo, processos fisiológicos, personalidades/divindades, agente de atividade profissional, instituições/ciências/artes/setores de atividade, processo/ técnica científica, sistema ideológico, religioso, civilizacional, político, entidade ou produto intelectual, sentimentos, fenómenos/estados atmosféricos, habitats geomorfológicos, o que aliás faz deste sufixo um dos de maior versatilidade no português (cf. Rio-Torto 2012).

\begin{tabular}{|l|l|l|l|}
\hline Base: radical nominal & Adj. sufixado em -ic- & Base: radical nominal & $\begin{array}{l}\text { Adj. sufixado } \\
\text { em -ic- }\end{array}$ \\
\hline academi- (academia) & académico & humoris- (humorista) & humorístico \\
\hline anedot- (anedota) & anedótico & melancol- (melancolia) & melancólico \\
\hline basalt- (basalto) & basáltico & metafor- (metáfora) & metafórico \\
\hline caucas- (cáucaso) & caucásico & milimetr- (milímetro) & milimétrico \\
\hline
\end{tabular}




\begin{tabular}{|l|l|l|l|}
\hline desert- (deserto) & desértico & octaedr- (octaedro) & octaédrico \\
\hline encefal- (encéfalo) & encefálico & poet- (poeta) & poético \\
\hline esquelet- (esqueleto) & esquelético & ritm- (ritmo) & rítmico \\
\hline fung- (fungo) & fúngico & semáfor- (semáforo) & semafórico \\
\hline gongor- (gôngora) & gongórico & sism- (sismo) & sísmico \\
\hline
\end{tabular}

Quadro III.4. Adjunção de -ic- a diferentes tipos semânticos de base

O quadro seguinte evidencia que os diferentes tipos semânticos de bases que se elencam neste capítulo em 3.1.2 e que denotam matérias/substâncias, objetos/artefactos, partes do corpo, processos fisiológicos, personalidades, agente de atividade profissional, instituições, ciências/artes/setores de atividade, processo/técnica científica, sistema ideológico, religioso, civilizacional, político, entidade ou produto intelectual, sentimentos, fenómenos/estados atmosféricos, habitats geomorfológicos, podem ser sufixadas por diversos sufixos adjetivalizadores. No quadro III.5 apenas se apresentam alguns dos sufixos mais representativos e disponíveis, como -an-, -al, -ar, -il, -ári-, -eir-, -ent-, -ic-, -ist-, -os-. Os sufixos -áce-, -ense e - $\hat{s}$ figuram na mesma coluna por terem escassa disponibilidade e quase não partilharem classes de bases comuns (com exceção das que denotam artefactos). Os sufixos -ic- (motociclístico, surfístico, twíttico) e -ist(a) (bloguista, coisista) são os sufixos mais versáteis, seguindo-se-lhes -al, -ar, -os-, -eir-, -ári-, -ent- e -an-.

\begin{tabular}{|c|c|c|c|c|c|c|c|c|}
\hline $\begin{array}{l}\text { Semântica } \\
\text { da base }\end{array}$ & $\begin{array}{l}\text {-áce-, } \\
\text {-ens-, -ês }\end{array}$ & $-a n-$ & $\begin{array}{l}-a l,-a r \\
-i l\end{array}$ & -ári- & -eir- & $\begin{array}{l}\text {-ent- } \\
\text {-os- }\end{array}$ & -ic- & -ist- \\
\hline Substância & sebáceo & & & & $\begin{array}{l}\text { corticei- } \\
\text { ro, sali- } \\
\text { neiro }\end{array}$ & $\begin{array}{l}\text { albumi- } \\
\text { noso } \\
\text { barrento }\end{array}$ & basáltico & \\
\hline ser vivo & $\begin{array}{l}\text { bacte- } \\
\text { riáceo } \\
\text { tulipá- } \\
\text { ceo }\end{array}$ & $\begin{array}{l}\text { bacteria- } \\
\text { no }\end{array}$ & $\begin{array}{l}\text { floral } \\
\text { florestal }\end{array}$ & $\begin{array}{l}\text { para- } \\
\text { sitário }\end{array}$ & & $\begin{array}{l}\text { juncoso } \\
\text { pulguento }\end{array}$ & $\begin{array}{l}\text { fúngico } \\
\text { espórico }\end{array}$ & \\
\hline $\begin{array}{l}\text { objeto, } \\
\text { artefacto }\end{array}$ & $\begin{array}{l}\text { turbiná- } \\
\text { ceo } \\
\text { castren- } \\
\text { se }\end{array}$ & & $\begin{array}{l}\text { ornamen- } \\
\text { tal }\end{array}$ & $\begin{array}{l}\text { ferro- } \\
\text { viário }\end{array}$ & $\begin{array}{l}\text { torpe- } \\
\text { deiro }\end{array}$ & & fílmico & \\
\hline $\begin{array}{l}\text { forma } \\
\text { geométrica }\end{array}$ & & & $\begin{array}{l}\text { octogonal } \\
\text { triangular }\end{array}$ & & & & cúbico & \\
\hline
\end{tabular}




\begin{tabular}{|c|c|c|c|c|c|c|c|c|}
\hline $\begin{array}{l}\text { parte do } \\
\text { corpo }\end{array}$ & & & $\begin{array}{l}\text { cerebral } \\
\text { muscular }\end{array}$ & $\begin{array}{l}\text { ma- } \\
\text { mário }\end{array}$ & dedeira & $\begin{array}{l}\text { membra- } \\
\text { noso nari- } \\
\text { guento }\end{array}$ & ovárica & \\
\hline estado & & & febril & & ordeiro & $\begin{array}{l}\text { amoroso } \\
\text { ciumento }\end{array}$ & colérico & terrorista \\
\hline evento & & & & & $\begin{array}{l}\text { traiçoei- } \\
\text { ro }\end{array}$ & $\begin{array}{l}\text { birrento } \\
\text { escanda- } \\
\text { loso }\end{array}$ & & \\
\hline $\begin{array}{l}\text { meteoroló- } \\
\text { gico }\end{array}$ & & & solar & & $\begin{array}{l}\text { grani- } \\
\text { zeira }\end{array}$ & $\begin{array}{l}\text { chuvento } \\
\text { chuvoso }\end{array}$ & $\begin{array}{l}\text { desértico } \\
\text { sísmico }\end{array}$ & \\
\hline $\begin{array}{l}\text { ciência/ } \\
\text { arte }\end{array}$ & & & \begin{tabular}{|l|} 
arquite- \\
tural \\
medicinal
\end{tabular} & & & & ballético & jazzista \\
\hline $\begin{array}{l}\text { personali- } \\
\text { dade, sis- } \\
\text { tema }\end{array}$ & & $\begin{array}{l}\text { maome } \\
\text { tano } \\
\text { pessoa- } \\
\text { no }\end{array}$ & & & & & $\begin{array}{l}\text { islâmico } \\
\text { napoleó- } \\
\text { nico }\end{array}$ & $\begin{array}{l}\text { budista } \\
\text { miguelista }\end{array}$ \\
\hline $\begin{array}{l}\text { entidade } \\
\text { intelectual }\end{array}$ & & & & & & & $\begin{array}{l}\text { anedó- } \\
\text { tico } \\
\text { satírico }\end{array}$ & alegorista \\
\hline instituição & & & $\begin{array}{l}\text { ministerial } \\
\text { parlamen- } \\
\text { tar }\end{array}$ & $\begin{array}{l}\text { ban- } \\
\text { cária }\end{array}$ & & & $\begin{array}{l}\text { autárqui- } \\
\text { co }\end{array}$ & $\begin{array}{l}\text { bolsista } \\
\text { cartelista }\end{array}$ \\
\hline agente & & & & & & & artístico & governista \\
\hline localidade & $\begin{array}{l}\text { sintren- } \\
\text { se fran- } \\
\text { cês }\end{array}$ & africano & & & $\begin{array}{l}\text { brasi- } \\
\text { leiro }\end{array}$ & & & paulista \\
\hline $\begin{array}{l}\text { intervalo } \\
\text { de tempo }\end{array}$ & & & \begin{tabular}{|l|} 
milenar \\
primaveril \\
outonal
\end{tabular} & diário & & $\begin{array}{l}\text { abrilento } \\
\text { invernoso }\end{array}$ & cíclico & $\begin{array}{l}\text { medieva- } \\
\text { lista }\end{array}$ \\
\hline $\begin{array}{l}\text { unidade de } \\
\text { medida }\end{array}$ & & & & & & & $\begin{array}{l}\text { milimé- } \\
\text { trico }\end{array}$ & $\begin{array}{l}\text { quilome- } \\
\text { trista }\end{array}$ \\
\hline
\end{tabular}

Quadro III.5. Distribuição de sufixos por tipos semânticos de bases

À grande flexibilidade na adjunção de sufixos adjetivalizadores a bases de natureza diversa, quer morfológica, quer semântica, acresce a possibilidade de uma mesma base ser combinável com vários sufixos: umas vezes os produtos são equivalentes (açórico, açoreano, açorenho, açorense, baamense, baamiano, baamês, costa-riquenho, costa-riquense), outras vezes assim não acontece, porque os adjetivos são gerados em épocas diferentes e/ou porque entretanto adquiriram sentidos mais específicos e diferenciados, como brasílico ('diz-se do povo e das coisas indígenas do Brasil') e brasileiro (natural, habitante do Brasil), japónico e japonês, ambos 'relativo ao Japão'. 
Em outras situações, e fruto da informação semântica específica de cada sufixo, o adjetivo adquire sentidos diferenciados, como em informação oficiosa vs. informação oficial ou muscular e musculoso, em treino muscular e jovem musculoso: a diferença entre muscular e musculoso reside no facto de muscular codificar uma relação de consubstancialidade (Rio-Torto 1991), de inerência, entre músculo(s) e o sistema a partir destes constituído, e no facto de musculoso codificar a existência de músculos bem desenvolvidos.

Não existindo padrões de correlação impositivos entre um sufixo adjetivalizador e uma estrutura morfológica de base, verificam-se todavia algumas tendências, não sistemáticas, de combinação preferencial entre determinados sufixos adjetivalizadores e alguns tipos morfológicos de bases. Assim, por exemplo:

(i) os sufixos -al e -ári- combinam-se frequentemente com bases nominais terminadas em -ção ou em - $(s) s \tilde{a} o$ que, em contexto derivacional, se reconfiguram alomorficamente em -cionou -(s)sion-: ascensão, ascensional; condição, condicional; demissão, demissionário; emoção, emocional; profissão, profissional; tradição, tradicional; torsão, torsionário;

(ii) os sufixos -al, -ári- e -in- estão presentes em muitas palavras herdadas do latim que mantêm a configuração formal das respetivas bases: por exemplo, em gradual e manual a base mantém - $\boldsymbol{d}$ - e - $\boldsymbol{n}$ - intervocálicos que com a evolução da língua sofreriam síncope (cf. grau, mão); em tumultuário e usuário preserva-se a vogal -u-; como em latim, em albino, aprilino, feminino, viperino, as bases replicam a configuração latina (albin-, aprilin-, femin-, viperin-), e não a portuguesa que lhes viria a corresponder (lat. alb- 'branco', port. alv-, em alvo/a; lat. april-, port. abril-, em abril; lat. viper-, port. vibor-, em víbora; lat. femin- 'mulher', port. feme-, em fêmea) (sobre a alomorfia cf. 1.1.3.2 deste livro); 
(iii) o sufixo -os- está presente em muitos derivados de origem latina, como afetuoso, frutuoso, insultuoso, tumultuoso, como se observa pela manutenção da vogal $-u$ - da base latina.

No conjunto dos sufixos adjetivalizadores denominais, há uns mais marcados como eruditos, quer pela sua configuração, quer pela das bases a que se acoplam, e outros não. Pela sua forma divergente face ao étimo comum, têm configuração erudita -an- (camiliano, toledano) face a -ão (coimbrão), -ense (bracarense, lisbonense) face a -ês (francês, mirandês) e -ári- (agrário) face a -eir- (brasileiro).

Como em outras circunstâncias derivacionais (Rodrigues 2008), os sufixos adjetivalizadores denominais mais eruditos, como -e(hercúleo, purpúreo) e -in- (purpurino, saturnino), têm tendência a acoplar-se a bases eruditas e/ou menos comuns, verificando-se a situação inversa com os não eruditos.

Muitos outros sufixos adjetivalizadores denominais combinam-se com bases de estrutura [ \pm erudita]; entre eles contam-se alguns de grande produtividade, como -ent- (barrento, mimento, quezilento, sonolento, sumento), -ic- (finalístico, fúngico, granítico, metálico, mimético, periodístico, platónico, plínico, querubínico), -ist(a) (aparelhista, epicurista, hedonista, retalhista, salinista), -os- (albuminoso, ferruginoso, mentiroso, pluvioso, poroso, sumptuoso, untuoso), -ud- (cabeçudo, orelbudo).

\subsubsection{Semântica das bases dos adjetivos denominais}

Os muitos sufixos adjetivalizadores combinam-se com bases que denotam uma variadíssima gama de entidades, objetos, matérias, eventos, atividades, sistemas conceptuais, elencada em Rio-Torto (2013) e que aqui se retoma.

Essas bases são radicais de nomes que denotam: 
1. matéria, substância (albuminoso, amiantáceo, asfáltico, basáltico, barrento, benzénico, cálcico, cevádico, corticeiro, ebânico, ferroso, fosfórico, granítico, insulínico, nafténico, salino, sebáceo, urânico, volfrâmico)

2. ser vivo (bacteriáceo, bacteriano, fúngico, parasitário, simiesco, arbustivo, espórico, juncoso, floral, florestal, tulipáceo, urtigoso)

3. objeto, artefacto (barométrico, ferroviário, fílmico, fotográfico, livresco, ornamental, palimpséstico, pórtico, [implante] protésico, semafórico, telefónico, turbináceo)

4. forma geométrica (cúbico, cilíndrico, esférico, octaédrico, octogonal, paralelepipédico, pentagonal, piramidal, triangular)

5. parte do corpo (brônquico, cerebral, encefálico, esofágico, esquelético, genómico, laríngico, mamário, membranoso, muscular, neurónico, orelhudo, ovárica, pancreático)

6. estado, sentimento (amoroso, ciumento, colérico, corajoso, febril, friorento, furioso, melancólico, ordeiro, paraplégico (<paraplegia), sonolento, terrorista), propriedade (belezuda)

7. evento (escandaloso, traiçoeiro);

8. fenómeno/estado atmosférico, habitat geomorfológico (ciclónico, chuvoso, desértico, equinocial, meteórico, meteorítico, oceânico, pantanoso, planáltico, sísmico, vulcânico)

9. ciência/arte, (setor de) actividade científica/artística (arquitetural, bacteorológico, ballético, cinematográfico, embriológico, ginecológico, medicinal, metalúrgico, museológico, musical, neurológico, oftalmológico), processo, técnica científica (abdominoscópico, fisioterápico)

10. sistema ideológico, religioso, civilizacional (budista, fundamentalista, islâmico, islamita, jesuíta, maometano, positivista) e político (esquerdoide, monárquico, republicano) 
11. entidade/produto intelectual (algorítmico, anedótico, dialógico, ensaístico, estereótipo, irónico, metafórico, paragógico, prototípico, satírico, sígnico)

12. instituição ([praxe] académica, arcádico, autárquico, bancária, camarário, ministerial, parlamentar), setor profissional (metalúrgico, tauromáquico)

13. agente de atividade profissional (acrobático, africanística, arquivística, artístico, bumorístico, jornalístico, náutico, propagandístico, tenístico, terapêutico)

14. personalidade (dantesco, gongórico, hamlético, homérico, lazarento, maquiavélico, napoleónico, petrarquista, queirosiano, salomónico, sebastiânico, socrático), entidade, divindade (capricorniano, ciclópico, faraónico, icárico, satânico, saturnino);

15. localidade (açoreano, aveirense, coimbrão, lisboeta, mirandês, paulista), país (açórico, angolano, brasileiro, brasílico, espanhol, francês, israelita, itálico, japónico (arroz), timorense), região (alentejano, algarvio, beirão, caucásico, escandinávico, ibérico, siberiano, tirolês), continente (africano, asiático, europeu), zona/ponto cardeal (nortenho, ocidental, oriental, polar, sulista)

16. período/intervalo temporal, epocal (diário, cíclico, episódico, fásico, invernoso, milenar, periódico, primaveril, outonal, rítmico, semanal, semestral, sistólico) ou civilizacional (medievalista, renascentista)

17. unidade de medida (milimétrico, quilométrico, voltaico)

\subsubsection{Morfologia e semântica dos adjetivos sufixados}

Na secção anterior atesta-se que um mesmo sufixo se pode combinar com bases semanticamente muito diversas e que vários sufixos podem atribuir um mesmo semantismo às bases a que se juntam. 
3.1.3.1 Adjetivos sufixados em -an(o/a), -ári(o/a), -eir(o/a), $-\operatorname{ens}(\boldsymbol{e}) \mathrm{e}-\hat{e} s$

$\mathrm{Na}$ atual sincronia, os sufixos $-a n(o / a),-\operatorname{eir}(o / a),-e n s(e)$ e $-\hat{e} s$ são os mais disponíveis e produtivos para a formação de adjetivos gentílicos, pátrios ou étnicos (cf. quadro III.6), como o atestam os exemplos -an(o/a) (africano, americano, cubano, paulistano, peruano), -eir(o/a) (brasileiro, pantaneiro, poveiro), -ens(e) (alcobacense, berlinense, funchalense, timorense), -ês (chinês, polonês, sudanês, tirolês), entre muitos outros. A consulta do Dicionário de Gentílicos e Topónimos (www.portaldalinguaportuguesa.pt) confirma esta assunção. Deve contudo registar-se a crescente representatividade de -ist(a) na formação de gentílicos, no Brasil, mas também em Angola e até em Portugal (Areán Garcia 2007: 287-299).

Já -ári $(o / a)$ não forma adjetivos detoponímicos, mas combina-se com nomes de classes semânticas variadas (alfandegário, bilionário, dentário, diário, embrionário, ferroviário, fragmentário, latifundiário, lendário, mamário, minifundiário, panfletário, partidário, rodoviário, tributário).

\subsubsection{Adjetivos sufixados em $-\operatorname{ent}(o / a),-o s(o / a)$ e $-u d(o / a)$}

Outros sufixos encontram-se mais acantonados na expressão de posse (de algo \pm alienável) de manifestação de uma propriedade, como -ent- (ciumento, lamacento, sum(ar)ento), -os- (brioso, espaçoso) e-ud- (raçudo, sisudo, sortudo), por exemplo, a que se associa por vezes a de "que causa $\mathrm{x}$ " (prazeroso, ternurento). Aos derivados em - $u d$ - acresce a marca de intensidade e/ou de excessividade ${ }^{38}$, de tal

38 Esta marca, aplicada a propriedades, permite ao sufixo combinar-se com algumas bases adjetivais, como (PB) boazuda, gostosuda. 
modo que barrigudo, peludo, rabudo, sortudo denotam 'que tem uma barriga demasiado proeminente', 'que tem pelos em excesso' e 'que tem muita sorte'. A avaliação pode ser positiva, como em bunduda (PB), rabuda, popozuda (PB), denotando alguém que tem 'bunda' (PB) ou um traseiro [popó] grande e bem feita/o. Em virtude do semantismo que codificam, estes sufixos combinam-se com bases que denotam matérias, substâncias (argiloso, barrento, catarrento, gelatinoso, lamacento, leitoso, sum(ar)ento, venenoso), estados/ sentimentos (amoroso, ardiloso, ciumento, pesaroso, ternurento), propriedades susceptíveis de serem alocadas a uma entidade (brioso, coceguento, presunçoso, vergonhoso). O sufixo -ud-combina-se com nomes de partes do corpo (barrigudo, beiçudo, cabeçudo, mamudo, narigudo, orelhudo, peludo, rabudo, trombudo), o que não acontece com os demais. Em função da semântica da base, alguns adjetivos em -ent- (birrento, peçonhento) significam 'que causa, que faz". $\mathrm{O}$ contraste entre alguns adjetivos corradicais em -ent- e em -os-, com catarrento, catarroso, ciumento e ciumoso, piolhento, piolhoso, parece indiciar que -os- tem um sentido mais intensivo e/ou expressivo que -ent-. De acordo com Teixeira (2009), num estudo levado a cabo sobre a interpretação semântica, por adultos e crianças, de sufixos adjetivalizadores, -os- parece estar associado no PB a um valor mais positivo (brigoso, cheiroso, gorduroso, gostoso, seboso) e -ent- a um valor mais negativo (briguento, gordurento, sebento).

\subsubsection{Adjetivos sufixados em $-e n g(o / a),-i(o / a)$ e $-i c ̧(o / a)$}

Os adjetivos sufixados em -eng(o/a) (mulherengo) e -iç(o/a) (outoniço, palhiço) denotam propensão, disposição. Em alguns casos (avoengo, realengo, solarengo) o sentido de similitude que -eng $(o / a)$ também possui encontra-se lexicalizado. Estes sufixos encontram-se presentemente não disponíveis para a produção de 
novos lexemas. Os sufixos -i(o/a) (gentio, doentio, baixio) e -iç(o/a) (castiço, enfermiço, mortiço) combinam-se com bases quer nominais (radical de gente) quer adjetivais (radical de casto, enfermo, morto, primeiriça 'diz-se de fêmea que é mãe pela primeira vez'). Em enfermiço e mortiço o sufixo denota 'propensão' e em doentio o sufixo denota similitude e/ou causatividade.

\subsubsection{Adjetivos sufixados em -esc $(o / a)$, -oid $(e)$, -áce $(o / a)$}

Exprimem similitude -esc(o/a) e -óid(e) (animalesco, animaloide). A estes dois sufixos estão associadas marcas negativas, observáveis em burlesco, dantesco, fradesco, livresco, quixotesco e em animaloide ou parvoide, sendo que em alguns casos as próprias bases já são marcadas negativamente (cf. radicais de burla e parvo). Todavia, as marcas disfóricas não são sistemáticas, como se observa em principesco e em muitos adjetivos cultos da esfera científica, como ov(al), ovoide, trianguloide, não depreciativos. Também -áce(o/a) denota similitude, mas aproximativa, e é usado sobretudo em termos técnicos da botânica (coroláceo, magnoliáceo, tulipáceo, welwitschiáceo) ou das ciências biológicas (bacteriáceo, larváceo). Os nomes equivalentes denotam espécimes animais ou vegetais (larváceos, magnoliáceas).

\subsubsection{Adjetivos sufixados em - ist $(a)$}

Um sufixo com um sentido relativamente especializado é -ist (a), pois forma adjetivos cuja significação pode ser descrita como 'especialista em', como por exemplo em médico urologista, técnico anestesista. Quando a base é o radical de um nome próprio, como Darwin, o adjetivo exprime uma relação de adesão ou de apoio intelectual, de simpatia ou de inclinação intelectual/afetiva, de partidário de sistema 
conceptual, ideológico, filosófico de Darwin. Muitos destes adjetivos em -ist(a) nominalizam com alguma frequência, funcionando portanto como nomes: os anestesistas, os urologistas, os darwinistas reuniram-se em congresso. Este sufixo é um dos mais disponíveis e produtivos na atual sincronia (adventista, afonsista, arsenalista, bolsista, cartelista, desenvolvimentista, despesista, divorcista, financista, fundista, futurista, governista, imediatista, intriguista, livre-cambista, miniaturista, narcisista, panfletarista, pragmaticista, primeiranista, progressista, quinhentista, sexista, sigilista, vicentista, vorticista, associando-se não apenas a nomes, mas também a adjetivos para formar novos adjetivos.

Uma das razões da sua grande disponibilidade prende-se com a grande diversidade de classes semântico-referenciais das bases nominais com que se combina, que denotam entidades humanas (afonsista, narcisista, vicentista), mas também instituições (arsenalista, bolsista, cartelista, governista), eventos, processos, atividades (intriguista, livre-cambista), estados (adventista, despesista, divorcista, futurista, imediatista, progressista, sigilista, vorticista), com os quais os demais sufixos adjetivalizadores, com exceção de -ic-, não mantêm uma especial propensão combinatória.

O sufixo -ist(a) carateriza-se por uma significativa versatilidade combinatória, pois, além de se combinar dominantemente com bases nominais (cf. cap. 3: 3.1.3), também se acopla a algumas bases verbais (cf. cap. 3: 3.3.14) e a algumas adjetivais. Neste conjunto se inscrevem os seguintes adjetivos deadjetivais, em que o produto apresenta um sentido idêntico ao que ocorre nos demais casos, ou seja, de 'apoiante de, simpatizante de, partidário de, especialista em': absolutista, absurdista, africanista, casualista, coletivista, corporativista, destrutivista, dualista, estruturalista, funcionalista, hegelianista, bumanitarista, imperialista, integralista, intimista, introspetivista, mentalista, mercantilista, minimalista, modernista, municipalista, neutralista, oportunista, otimista, perpetuísta, preciosista, presidencialista, sentimentalista, simplista, sonambulista, tropicalista, vigarista. 
Sob o ponto de vista morfológico, as bases adjetivais podem ser simples (intimista, otimista, oportunista, simplista) ou complexas (begelianista, tropicalista), e também podem corresponder a adjetivos graduáveis (moderno, simples) ou não (estrutural, mental, municipal, presidencial).

\subsubsection{Adjetivos sufixados em -al, -ar, $-\operatorname{eir}(o / a)$ e $-i c(o / a)$}

Estes sufixos, entre os quais se encontram alguns dos mais disponíveis para a produção de adjetivos denominais, como -al (artesanal, autoestradal, caricatural, fenomenal, semestral, sentimental, teatral), -ar (angular, (carro) celular, espetacular, familiar, medular, milenar, modular, nodular, pendular, perpendicular, polar, protocolar), -eir-(aventureiro, certeiro, vidreira [indústria]) e, acima de todos, -ic- 39 (académico, alcoólico, algébrico, anedótico, basáltico, caucásico, desértico, encefálico, esquelético, fúngico, gongórico, humorístico, melancólico, metafórico, metálico, metódico, milimétrico, octaédrico, rítmico, semafórico, sísmico), não possuem sentido específico e permanente que os possa diferenciar de forma sistemática, sendo assim portadores dum semantismo genérico, de 'relativo a', adaptável em função das informações semânticas adstritas às bases com que se concatenam. Em bebida alcoólica o adjetivo informa da presença significativa de teor de álcool, mas em coma alcoólico, o adjetivo equivale a 'provocado pelo álcool'. Já em trabalho artesanal o adjetivo equivale a 'feito por artesão, de forma não industrial', mas em trabalho semestral o adjetivo equivale a 'que dura um semestre'. Em pessoa sentimental o adjetivo equivale

39 O sufixo -ic- combina-se até mesmo com bases adjetivais, nomeadamente com muitas portadoras de -ist-, como em altruístico, alarmístico, amadorístico, apologístico, clubístico, conceptualístico, culturístico, darwinístico, expansionístico, lobístico, militarístico, triunfalístico. 
a 'que manifesta facilmente e/ou intensamente os seus sentimentos, que se emociona facilmente'. Em jovem aventureiro o adjetivo equivale a 'que gosta da aventura'; e em indústria vidreira o adjetivo equivale a 'cuja matéria-prima é o vidro'. Estes exemplos abonam em favor da não especialização semântica de muitos dos sufixos adjetivalizadores denominais e da sua ductilidade em função do semantismo da base e do nome nuclear que modificam.

Todavia, -eir- em comportamento eleiçoeiro, interesses eleitoreiros, atitude politiqueira veicula sentido depreciativo.

\subsubsection{Adjetivos detoponímicos e adjetivos denominais}

Uma derradeira manifestação da grande amplitude combinatória e ao mesmo tempo do grau de (in)especificidade semântica de muitos dos sufixos adjetivalizadores denominais consubstancia-se através da comparação (cf. Quadro III.6) do comportamento de vários sufixos na formação de adjetivos denominais e na de um seu subconjunto: o dos adjetivos gentílicos, todos nominalizáveis, que predicam uma propriedade em função do país, da região, da província, da localidade de nacimento ou de procedência.

No quadro que se segue, parcialmente retomado de Rio-Torto (1988: 223-230), arrolam-se adjetivos denominais gentílicos (coluna da direita) e adjetivos denominais cujas bases são não toponímicas (coluna do meio), a fim de se verificar em que medida há ou não tendência para uma distribuição disjunta ou não de um mesmo sufixo pelos dois conjuntos.

\begin{tabular}{|l|l|l|}
\hline Sufixos & Adjetivos denominais & Adjetivos gentílicos \\
\hline $1 .-$ ach- & friacho; verdacho & corvacho; pegacho; riacho \\
\hline 2.-ac- & dionisíaco; maníaco & austríaco \\
\hline 3.-ad- & $\begin{array}{l}\text { barbado; dentado; labiado; } \\
\text { mentolado; rosado; salmonado }\end{array}$ & ---- \\
\hline
\end{tabular}




\begin{tabular}{|c|c|c|}
\hline 4.-aic- & farisaico; prosaico & judaico; pirinaico \\
\hline 5.-al & $\begin{array}{l}\text { ambiental; artesanal; conjugal; } \\
\text { fundamental; repertorial; semestral; } \\
\text { sentimental; teatral; triunfal }\end{array}$ & provençal \\
\hline 6.-an- & $\begin{array}{l}\text { camoniano; luterano; parnasiano; } \\
\text { queirosiano; pessoano }\end{array}$ & $\begin{array}{l}\text { africano; alagoano; angolano; } \\
\text { iraniano; iraquiano; kuwaitiano; } \\
\text { murciano; romano; trancosano; } \\
\text { tanzaniano; valenciano }\end{array}$ \\
\hline 7.-ão & cardão; gargantão; pancão & $\begin{array}{l}\text { barrosão; braganção; coimbrão; } \\
\text { ilhavão; leirião; marinhão; } \\
\text { palmelão; sesimbrão; setubalão; } \\
\text { sintrão; sousão }\end{array}$ \\
\hline 8.-ar & $\begin{array}{l}\text { complementar; espectacular; } \\
\text { exemplar; familiar; medular }\end{array}$ & angolar; insular; kosovar \\
\hline 9.-ári- & $\begin{array}{l}\text { alfandegário; dentário; diário; } \\
\text { ferroviário; fragmentário; } \\
\text { latifundiário; lendário; mamário; } \\
\text { numerário; panfletário; partidário; } \\
\text { rodoviário; tributário }\end{array}$ & ----- \\
\hline 10.-at- & sensato, timorato & felgarato; larinhato; maiato \\
\hline 11.-eir- & $\begin{array}{l}\text { aventureiro; certeiro; cervejeiro; } \\
\text { costumeiro; femeeiro; interesseiro; } \\
\text { pesqueiro }\end{array}$ & $\begin{array}{l}\text { brasileiro; buarqueiro; cartaxeiro; } \\
\text { machiqueiro; mineiro; poveiro; } \\
\text { sanjoaneiro; seixaleiro; soajeiro }\end{array}$ \\
\hline 12.-ej- & castrejo & $\begin{array}{l}\text { alcoutinejo; colarejo; crastejo } \\
\text { fianejo; marvanejo, sertanejo }\end{array}$ \\
\hline 13.-eng- & mulherengo; solarengo & mertelengo; sumarengo \\
\hline 14.-enb- & ferrenbo & $\begin{array}{l}\text { açorenho; barranquenho; belizenho; ca- } \\
\text { celenho; estremenho; ferreirenho; lagoe- } \\
\text { nho; nortenho; quadrasenbo; quintenbo }\end{array}$ \\
\hline 15.en- & terreno & chileno; nazareno; madrileno \\
\hline 16.ens- & forense, bortense, nortense & $\begin{array}{l}\text { aveirense; berlinense; bracarense; } \\
\text { farense; leiriense; macaense; } \\
\text { ovarense; parisiense; portuense; } \\
\text { sanjoanense; setubalense; timorense; } \\
\text { torreense; viseense }\end{array}$ \\
\hline 17.-ent- & $\begin{array}{l}\text { barrento; catarrento; ciumento; } \\
\text { peçonbento; sum(ar)ento }\end{array}$ & ----- \\
\hline 18.-e- & férreo; purpúreo & $-\mathbf{A}^{----}$ \\
\hline 19.-ês & cortês; pedrês & $\begin{array}{l}\text { dinamarquês; escocês; francês; } \\
\text { holandês; irlandês; japonês; } \\
\text { luxemburguês; mirandês; ruandês; } \\
\text { sudanês; tirolês }\end{array}$ \\
\hline 20.-esc- & $\begin{array}{l}\text { animalesco; burlesco; folhetinesco; } \\
\text { fradesco; livresco; quixotestco; }\end{array}$ & ----- \\
\hline 21.-estr- & pedestre & campestre; terrestre \\
\hline 22.-et- & forreta & catarineta; fonteta; lisboeta \\
\hline 23.eu & ilhéu & europeu; guinéu \\
\hline $24 .-i-$ & gentio, tardio & algarvio \\
\hline $25 .-i c ̧-$ & enfermiço; palbiço; roliço & aranbiço; campaniço \\
\hline
\end{tabular}




\begin{tabular}{|c|c|c|}
\hline 26.-ici- & natalicio; adventício & ----- \\
\hline 27.-ic- & alegrico (reg.); tontico (reg.) & mafarico; minderico \\
\hline 28.-ic- & $\begin{array}{l}\text { alegórico; algébrico; artístico; } \\
\text { calórico; granítico; metódico; } \\
\text { melancólico }\end{array}$ & açórico; brasílico; balcânico; itálico \\
\hline 29.-il & febril; primaveril; senhoril & ----- \\
\hline 30.-in- & $\begin{array}{l}\text { castorino; cristalino; manuelino; } \\
\text { pombalino; purpurino; uterino }\end{array}$ & $\begin{array}{l}\text { amarantino; flandrino; londrino; } \\
\text { marroquino; pontevedrino }\end{array}$ \\
\hline 31.-isc- & mourisco & flandrisco \\
\hline 32.-ist- & budista; carreirista; terrorista & $\begin{array}{l}\text { alfamista; cabindista; dondista; } \\
\text { freixinista; buambista; ipiranguista; } \\
\text { macaista; malaquista; paranista; } \\
\text { paulista; pembista }\end{array}$ \\
\hline 33.-it- & ismaelita & israelita; moscovita; vietnamita \\
\hline 34.-oid- & animaloide; esferoide; ovoide & ----- \\
\hline 35.-ol & -- & espanbol \\
\hline 36.-onh- & medonbo; enfadonbo; risonbo & ----- \\
\hline 37.-orr- & beatorro & nisorro \\
\hline 38.-os- & $\begin{array}{l}\text { amoroso; brioso; gelatinoso; leitoso; } \\
\text { venenoso; vergonhoso }\end{array}$ & 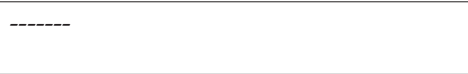 \\
\hline 39.-ot- & patriota & $\begin{array}{l}\text { cairota; gafanhoto; marinhoto; } \\
\text { minboto; paivoto; penaguioto; } \\
\text { vilachoto }\end{array}$ \\
\hline 40.-ud- & $\begin{array}{l}\text { abelbudo; barrigudo; cabeludo; } \\
\text { pontudo; sortudo; trombudo }\end{array}$ & ----- \\
\hline
\end{tabular}

Quadro III.6. Comportamento dos sufixos adjetivalizadores denominais na formação de adjetivos denominais gentílicos e não gentílicos

Dos quarenta sufixos aqui listados, apenas -ol e -orr- não ocorrem na formação de outros adjetivos que não os gentílicos. De -ol pode acrescentar-se que forma nomes, como tintol, urinol, e de -orr- que funciona como avaliativo, em beatorra, velhorro. A base do adjetivo patriota, ainda que não seja um topónimo (razão pela qual não figura na coluna da direita), é um nome de território.

No total de quarenta sufixos, apenas onze (-ad-, -ári-, -ent-, -e-, -esc-, -íci-, -il, -óid-, -onb-, os-, -ud-) não se combinam com bases toponímicas. A estes poder-se-ia acrescentar -el-, que ocorre em alguns adjetivos avaliativos, como doidela/o, magre- 
lo, magricela, e num adjetivo detoponímico: corvelo, da ilha do Corvo, presentemente substituído por corvense (Rio-Torto 1993: 437-439).

Se excetuarmos o sufixo erudito -e- (purpúreo, róseo) e -il (infantil, juvenil, pueril, varonil), presentes sobretudo em palavras de origem ou de traça erudita, e -onb-, também indisponível, restam essencialmente os sufixos tipicamente associados à expressão de posse (-ent-, -os-, -ud-) e/ou de similitude pejorativamente encarada (-esc-, -oid-), e por isso alheados da adjetivalização gentílica. Existe contudo o topónimo Capeludos de Aguiar, no concelho de Vila Pouca de Aguiar, distrito de Vila Real, que tem por base o radical de Capelo, o qual também está na origem do conhecido Vulcão dos Capelinhos, localizado na Ponta dos Capelinhos, freguesia do Capelo da Ilha do Faial (Açores).

\subsection{Adjetivos denumerais}

Os adjetivos denumerais têm por base radicais numerais. Os sufixos usados podem ser comuns aos adjetivos denominais, assim acontecendo em -al (centesimal, decimal), e podem ser específicos da subclasse dos adjetivos denumerais, como -av- (oitavo).

Em função do sufixo usado, o adjetivo pode ter valor intensivo ou pode funcionar como adjetivo e/ou como numeral ordinal, multiplicativo e fracionário.

Os adjetivos sufixados em -ão têm por base radicais de numerais cardinais (radical trint-, quarent-, cinquent-, em trintão, quarentão, cinquentão) e significam 'que tem ou aparenta ter, de foma bem marcada/intensa, os anos que a base denota', carreando assim a marca de intensidade presente em -ão.

Os adjetivos sufixados em -al que têm por base radicais de numerais ordinais, como decim-, centesim-, em decimal, cen- 
tesimal, significam 'relativo ao número que a base denota' (cf. sistema centesimal).

Os denumerais que funcionam como numerais ordinais (décimo, vigésimo, trigésimo, nonagésimo, milésimo) são palavras eruditas importadas do latim. Também de origem e de estrutura erudita são os denumerais unitário, binário, ternário, quaternário.

$\mathrm{O}$ valor fracionário é codificado por -av- (oitavo, trintavo, quarentavo), significando cada um 'dividido em, ou que contém $x$ partes, frações' e em que $x$ representa o que a base denota. Nos demais casos o sufixo ganhou autonomia lexical, assumindo-se como palavra lexical autónoma, como se observa em onze/treze/ catorze/vinte/trinta avos.

Para a formação de adjetivos numerais com valor multiplicativo recorre-se a -(u)pl- (quádruplo, quíntuplo, sêxtuplo, séptuplo, óctuplo, nônuplo, décuplo, cêntuplo), que significam ' $x$ vezes mais o que a base denota'. Trata-se, em todos os casos, de palavras de origem e de estrutura eruditas.

\subsection{Adjetivos deverbais: bases, sufixos, produtos}

Os adjetivos deverbais do português são formados por dois tipos de mecanismos: a sufixação (cap. 3: 3.3.1-17) e a conversão (cap. 3: 3.3.18-20), seja esta do radical (pisco), do tema (penetra) ou do particípio passado (casado).

Em cada subsecção de 3.3 descrevem-se os sufixos e as bases (sob os pontos de vista morfológico e sintático-semântico) que estes selecionam, assim como as significações que ambos aportam aos adjetivos. Os sufixos apresentam-se por ordem decrescente de representatividade.

Em Português, os adjetivos deverbais são formados com os seguintes sufixos (neste quadro por ordem alfabética): 


\begin{tabular}{|c|c|}
\hline -ão (refilão, resmungão) & -ist(a) (consumista, trocista) \\
\hline$-\boldsymbol{a z}$ (mordaz, tragaz) & $-i v(o / a)$ (processivo) \\
\hline -deir (o/a) (caideiro, i) & -nt(e) (aterrorizante, glorificante) \\
\hline -diç (o/a) (espantadiço, esquecediço) & $\begin{array}{l}\text {-óri(o/a) (expulsório, relambório } \\
\text { 'preguiçoso') }\end{array}$ \\
\hline -di (o/a) (escorregadio, lavradio) & -os(o/a) (queixoso, zeloso) \\
\hline -dor (cumpridor, reparador) & -tiv(o/a) (despertativo, refrigerativo) \\
\hline -dour (o/a) (casadouro, valedouro) & -tóri(o) (bajulatório, circulatório) \\
\hline -eir (o/a) (beijoqueiro, erreiro) & -vel (contável, prestável) \\
\hline -ent (o/a) (embirrento, resmunguento) & \\
\hline
\end{tabular}

Quadro III.7. Adjetivos deverbais e respetivos sufixos

Muitos dos sufixos que dão origem a adjetivos deverbais estão também presentes na formação de nomes deverbais (cf. secção 2.4.2).

Nos adjetivos, a flexão em género não representa alteração de significação; por isso não elencamos separadamente as formas femininas dos sufixos. A alternância de genéro de masculino para feminino faz-se, no caso dos adjetivos em -deir(o), -eir(o), -tóri(o), -óri(o), -tiv(o), -iv(o/a), ${ }^{40}$-ent $(o),-\operatorname{diç}(o),-d i(o),-d o u r(o),-\tilde{a} o,-o s(o)$, através da comutação do marcador de classe -o por - $a$. Nos adjetivos, as formas femininas ilustram apenas uma alternância de flexão e não uma mudança lexical. Isto deve-se ao facto de não haver valor semântico distinto entre a forma masculina do adjetivo e a forma feminina. Na formação de nomes, a alternância de género acarreta, por vezes, valor semântico diferente. Por isso, nesse caso, as formas femininas são consideradas autonomamente em relação às formas masculinas.

As significações destes produtos adjetivais são genericamente as seguintes:

(i) qualidade de 'agente/causa' ('que V'), que pode ser aplicada a humanos (bebé chorão, homem trabalhador), a animais (ca-

40 Para a delimitação de -tóri $(o)$, -óri $(o)$, -tiv $(o)$, -iv(o), veja-se o que foi referido na secção 2.4 .2 a propósito dos produtos nominais. 
valo trotador, cão guardador, animal hospedeiro), a plantas (planta trepadeira), a instrumentos (aparelho aparador), a substâncias (produto adstringente), ou não ser específica quanto a esta aplicação.

(ii) qualidade de 'objeto'41 ('que é Vdo'): lavável, contornável, assado, congelado.

\subsubsection{Adjetivos sufixados em -dor}

A forma da base verbal a que -dor se anexa é a do tema do presente (esclarecedor, cumpridor). A forma feminina é -dora.

As estruturas morfológicas dos verbos a que o sufixo -dor se junta são as seguintes:

(i) bases simples não derivadas (cumprir> cumpridor, madrugar> madrugador);

(ii) bases simples derivadas (verbos conversos) (batalhar> batalhador);

(iii) bases complexas não derivadas (conversar>conversador, preservar $>$ preservador);

(iii) bases complexas derivadas formadas por prefixação (apadrinhar > apadrinhador; desfrutar > desfrutador; embaraçar> embaraçador; esfarrapar>esfarrapador; refilar>refilador; ressoar $>$ ressoador), sufixação (amenizar>amenizador;

${ }^{41}$ A distinção entre adjetivos que designam 'agente/causa' e 'objeto' aqui utilizada corresponde à que Rainer (1999: 4597-4610) faz entre adjetivos ativos e passivos. A nossa opção vinca de modo mais direto as relações entre o significado do produto adjetival e o esquema léxico-conceptual do verbo base. Os subgrupos que Rainer estabelece (ativos: puros, potenciais, disposicionais; passivos: potenciais, deônticos, participais) dizem respeito às significações que variam em produtos com o mesmo sufixo. Neste trabalho, descreve-se o contributo de cada sufixo na abordagem específica dos seus produtos. 
cortejar> cortejador; escurecer $>$ escurecedor; pacificar $>p a-$ cificador; parafrasear> parafraseador) e por circunfixação (embrutecer $>$ embrutecedor; esclarecer $>$ esclarecedor).

Tal como na formação de nomes, este sufixo agrega-se a bases eruditas e não eruditas.

No que diz respeito aos tipos sintático-semânticos de bases, o sufixo -dor anexa-se preferencialmente a bases transitivas, a que se seguem as inergativas e inacusativas.

Das bases transitivas, as mais numerosas são as indicadoras de desempenho (cometer>cometedor, esbanjar>esbanjador, escrever $>$ escrevedor), as causativas (desbravar $>$ desbravador, desagravar>desagravador, harmonizar>harmonizador) e as ornativas (guarnecer>guarnecedor, ornamentar>ornamentador, polinizar>polinizador). Existem muitos outros tipos transitivos como bases destes produtos (Rodrigues 2008).

As bases inergativas são sobretudo indicadoras de desempenho (batalhar>batalhador, gesticular>gesticulador), de emissão de som (choramingar $>$ choramingador, gemer $>$ gemedor, rosnar $>$ rosnador), de modo de moção (flutuar>flutuador, passear $>$ passeador, trepar $>$ trepador), entre outros. As bases inacusativas são sobretudo de verbos de estado/existência (predominar $>$ predominador, sofrer $>$ sofredor), mover-se em direção específica (migrar>migrador) e aparecimento (deflagrar $>$ deflagrador).

Os sentidos dos produtos adjetivais sufixados em -dor são parafraseáveis por 'que V', pelo que os adjetivos designam 'causa'. O contributo semântico do sufixo para estes produtos é o mesmo que ocorre na formação dos nomes (cf. cap. 2: 2.4.2.1.), ou seja, é de [que tem a função de]. Nesta medida, os adjetivos que são formados através deste sufixo designam, matricialmente, a qualidade de exercer a função denotada pelo verbo base. Assim, pessoa batalhadora designa alguém que batalha, no exercício 
dessa função, e independentemente de ter ou não essa capacidade; aparelho sorvedor de poeiras é o que tem por função sorver, mas um produto solvente tem a propriedade de solver; uma bóia flutuadora tem por função flutuar, enquanto um hotel flutuante é aquele que, como um cruzeiro, tem a capacidade de flutuar (cf. cap. 3: 3.3.4). Por contraste com os adjetivos em -dor, que designam 'qualidades concernentes ao exercício de uma função', sem indicação de capacidade para tal, os adjetivos em -deir- (moça namoradeira) indicam a qualidade dependente de uma funcionalidade, ou seja, uma capacidade de efetuar o evento descrito pelo verbo (cf. cap. 3: 3.3.2). É possível que se esteja a esbater a diferença existente entre o valor de -dor e o de -nte, pois em várias circunstâncias os produtos corradicais são usados como equivalentes (potência administradora e potência administrante, fenómeno atemorizador e atemorizante, debate problematizador e problematizante).

Nos adjetivos em -dor, a significação de 'que tem a função de $\mathrm{V}$ ' pode corresponder ao argumento externo de verbos inergativos (homem blasfemador, cão ladrador) e de verbos transitivos (momento inspirador, sono reparador). No entanto, também se encontram significações de 'causa' que não correspondem a nenhum dos argumentos da base verbal (químico chovedor 'que faz chover'; exercício suador 'que faz suar'), tal como acontece na formação de nomes através deste sufixo (cf. cap. 2: 2.4.2.1.)

A significação de 'que tem a função de' pode ainda corresponder ao argumento interno de verbos inacusativos (ave migradora), mas não ao argumento interno de verbos transitivos (indivíduo bebedor vs. *vinho bebedor).

Assim, o sentido de [que tem a função de] pode ocorrer em produtos em -dor com base em verbos cuja estrutura léxico-conceptual não contém um elemento causativo definido, como é o caso de 
verbos como morar, migrar ${ }^{42}$. No entanto, não ocorre com base em verbos que apenas contêm um Objeto [-ativo, +afetado], como morrer ou nascer. Por esse motivo, os verbos inacusativos que servem de base a estes produtos não são os de tipo incoativo, mas de movimento e de estado/existência.

Tal como na formação de nomes, não existe relação direta entre um argumento da base verbal e a significação do produto em -dor. $\mathrm{O}$ adjetivo deflagrador [aparelho deflagrador] qualifica uma 'causa'. No entanto, o verbo deflagrar é inacusativo, pelo que não tem na sua estrutura argumental um argumento que seja preenchido léxico-conceptualmente por Causa.

\subsubsection{Adjetivos sufixados em $-\operatorname{deir}(o / a)$}

O sufixo - $\operatorname{deir}(o / a)$ anexa-se ao tema do presente da base verbal (trazer > trazedeiro) e tem preferência por bases de estrutura não erudita.

São as seguintes as estruturas morfológicas das bases verbais a que o sufixo -deir- se anexa: (i) bases simples não derivadas (andar $>$ andadeiro, cair $>$ caideiro, ganhar $>$ ganhadeiro); (ii) bases simples conversas (casar>casadeiro, fiar $>$ fiadeiro, malhar $>$ malhadeiro); (iii) bases complexas derivadas, formadas por prefixação: agasalhar $>$ agasalhadeiro, arrastar $>$ arrastadeiro. Não se encontram bases sufixadas nem circunfixadas.

As bases dos produtos em -deir- são sobretudo transitivas. As bases transitivas são indicadoras de desempenho (comer> comedeiro, mandar $>$ mandadeiro, trabalhar $>$ trabalhadeiro),

42 Trata-se de verbos, por vezes de dois lugares, como morar, suportar, em que o argumento que ocupa a função sintática de sujeito não é preenchido por um papel léxico-conceptual de 'causa', nem interna, nem externa. (Rodrigues 2008: 274; Levin \& Rappaport Hovav 1995: 120). 
causativas (assar $>$ assadeiro, lavar $>$ lavadeiro, podar $>$ podadeiro), resultativas (urdir>urdideiro), de mover objeto em direção específica (arrastar>arrastadeiro). As bases inergativas são indicadoras de desempenho (fumar $>$ fumadeiro, namorar $>$ namoradeiro), de emissão de som (palrar>palradeiro), de modo de moção (bailar>bailadeiro, trepar> trepadeiro), de emissão de substância (cuspir>cuspideiro). As bases inacusativas são de mover-se em direção específica (cair $>$ caideiro) e de mudança de estado (casar $>$ casadeiro).

Os semantismos dos produtos adjetivais em -deir-são de dois tipos:

(i) 'agente/causa': qualidade de um instigador de um evento (parideira, poedeira);

(ii) 'objeto': qualidade de um objeto do evento, coincidente com o argumento interno na função de sujeito de verbo inacusativo (casadeira), ou com argumento interno na função de objeto de verbo transitivo (caçadeira).

Os adjetivos que designam 'agente' ou 'causa', conforme aplicados a entidades [+/-humanas], coincidem semanticamente com o argumento externo do verbo base, que pode ser transitivo ou inergativo $^{43}$. São produtos de verbos transitivos que têm significação de 'causa/agente' os seguintes exemplos: [galinha] poedeira, [mulher] varredeira, [mulher] parideira, [animal] lavradeiro, [homem] comedeiro, [objeto] roçadeiro, etc. São produtos de verbos inergativos com significação de 'agente/causa' produtos como [planta] trepadeira, [moça] bailadeira, [rapaz] andadeiro, [rapaz] namoradeiro, [papagaio] palradeiro, [homem] rezadeiro, etc.

43 Não se encontraram em Rodrigues (2008) produtos adjetivais em -deir- que designem qualidade de 'causa/agente' ou 'objeto' não coincidente com um argumento do verbo base, ao contrário do que ocorre nos produtos nominais (cf. 2.4.2.2. e 2.4.2.3 deste livro). 
Os adjetivos que designam 'objeto' podem corresponder ao argumento interno de verbos transitivos e de verbos inacusativos. São exemplos de adjetivos que manifestam correspondência com o argumento interno de verbos transitivos produtos como [casaco] trazedeiro, [ave] caçadeira, [caminho] andadeiro, [alimento] assadeiro, entre outros.

São exemplos de adjetivos que manifestam correspondência com o argumento interno de verbos inacusativos produtos como: [edifício] caideiro, [moça] casadeira e [planta] alastradeira.

Repare-se que a mesma base verbal pode dar origem a significações de 'agente/causa' e de 'objeto' em simultâneo. É este o caso de caçadeira que designa 'qualidade daquilo que é próprio para ser caçado' e 'qualidade daquilo que caça', bem como de andadeiro que significa 'qualidade de caminho que é fácil de andar' e 'qualidade daquele que anda muito'. Esta duplicidade deve-se ao contributo semântico de [que tem a funcionalidade de] do sufixo. Em contraste com os adjetivos em -dor, que designam 'qualidades concernentes ao exercício de uma função', sem indicação de capacidade para tal, os adjetivos em -deir-indicam a qualidade dependente de uma funcionalidade, ou seja, uma capacidade de efetuar o evento descrito pelo verbo. Nesta medida, é natural a extensão de 'frequente' que ocorre nestes produtos (e.g. andadeiro, bailadeiro, rezadeiro), tal como também se verifica para os produtos nominais (cf. cap. 2: 2.4.2.2 e 2.4.2.3).

Atente-se na distinção entre mulher trabalhadora e mulher trabalhadeira. O primeiro designa, na sua significação composicional, uma mulher 'que tem a função de trabalhar', enquanto o segundo aponta uma mulher 'que tem a capacidade de trabalhar', ou seja, que tem as caraterísticas necessárias para efetuar o evento. $\mathrm{O}$ mesmo ocorre em relação aos objetos. Uma roupa trazedeira é uma roupa 'que tem as caraterísticas necessárias para se poder trazer quotidianamente'. É este traço semântico que possibilita que os 
produtos em -deir- designem não só 'agente/causa', mas também o 'objeto' de verbos transitivos. Nos produtos em -dor, o 'objeto' corresponde ao argumento interno de verbos inacusativos, mas não ao argumento interno de verbos transitivos. Saliente-se que os verbos inacusativos que estão na base dos produtos em -dor referidos são, semanticamente, de movimento em direção específica, estado/existência.

\subsubsection{Adjetivos sufixados em $-\operatorname{dour}(\boldsymbol{o} / a)$}

O sufixo $-\operatorname{dour}(o / a)$ anexa-se ao tema do presente da base verbal (morrer $>$ morredouro) e forma adjetivos que significam [propício a/próprio para].

Este sufixo prefere bases de estruturas não eruditas e anexa-se a bases verbais com as seguintes estruturas morfológicas: (i) bases simples não derivadas (amar>amadouro, temer $>$ temedouro, valer $>$ valedouro, vender $>$ vendedouro); e (ii) bases simples derivadas (verbos conversos) (casar>casadouro).

Os adjetivos portadores deste sufixo são construídos com base em verbos transitivos e inacusativos. As bases transitivas são as mais representadas, com tipos semânticos de indicação de desempenho (comer $>$ comedouro, marcar $>$ marcadouro, vessar $>$ vessadouro), causativos (lavar> lavadouro), de experienciador-sujeito (amar> amadouro, temer>temedouro). As bases inacusativas ${ }^{44}$ são sobretudo de estado/existência (aturar>aturadouro, valer $>$ valedouro,

${ }^{44}$ Em Bluteau (1712-1728) o verbo valer encontra-se ainda registado apenas na construção inacusativa. A construção transitiva é posterior e manifesta a inclusão da causa externa (cf. Chierchia 2004). O verbo aturar possui dois argumentos internos, na acepção de Levin \& Rappaport Hovav (1995), sendo por isso, apesar de diádico, inacusativo, dado que o argumento que ocupa a função de sujeito não manifesta semanticamente 'causa'. É essa ausência de 'causa' que permite a classificação de viver também como inacusativo. 
viver $>$ vivedouro) e de desaparecimento (morrer $>$ morredouro, perecer>perecedouro). Não se encontram produtos adjetivais com base em verbos inergativos.

Os adjetivos em -dour- apresentam as significações de 'objeto' e de 'causa'. As de 'causa' são exemplificadas por roçadouro, varredouro e vessadouro. Nestes produtos, o significado corresponde à qualidade da causa que preenche o argumento externo das bases. As significações de 'objeto' são mais numerosas e podem corresponder ao argumento interno de verbos transitivos, como amadouro, comedouro, entregadouro, lavadouro, marcadouro, segadouro, semeadouro, temedouro, vendedouro. Nestes casos os produtos são parafraseáveis por 'que está/tem (em) condições de ser Vdo'. Um alimento comedouro 'está em condições de ser comido', um indivíduo amadouro 'é digno de ser amado', uma criatura temedoura 'tem condições para ser temida'.

As significações de 'objeto' podem ainda corresponder ao argumento interno de um verbo inacusativo, como morredouro, perecedouro, rendedouro, valedouro, vivedouro. Neste caso, os adjetivos são parafraseáveis por 'que está/tem (em) condições de V'. Um indivíduo vivedouro 'está/tem (em) condições de viver muito tempo'; um negócio rendedouro 'está/tem (em) condições de render muito dinheiro'.

Existem produtos que correspondem ao primeiro argumento interno de um verbo inacusativo de dois lugares, como aturadouro ou duradouro. Mais uma vez se verifica que não há ligação unívoca entre os semantismos dos produtos e um argumento ou papel léxico-conceptual do verbo base. Assim, o denominador comum aos adjetivos em -dour- é devido ao contributo semântico do sufixo, que definimos como [propício a/próprio para]. Um campo semeadouro 'é propício para ser semeado', um instrumento roçadouro 'é próprio para roçar', uma erva segadoura 'está própria para ser segada'. 


\subsubsection{Adjetivos sufixados em $-n t(e)$}

O sufixo - nt(e) anexa-se ao tema do presente da base verbal (correr > corrente) e forma adjetivos (material absorvente) que significam [que tem a propriedade de].

O sufixo, que tem preferência por bases de estruturas não eruditas, anexa-se a bases verbais com as seguintes estruturas morfológicas: (i) bases simples não derivadas (citar $>$ citante, correr $>$ corrente, pender>pendente); (ii) bases simples conversas (anestesiar>anestesiante, pactuar $>$ pactuante, principiar $>$ principiante); (iii) bases complexas não derivadas (dissolver $>$ dissolvente, implorar $>$ implorante, remanescer>remanescente); (iv) bases complexas derivadas formadas por sufixação (certificar>certificante, evangelizar>evangelizante, hebraizar>hebraizante, lubrificar>lubrificante) e por prefixação (atenuar>atenuante, cooperar>cooperante, englobar>englobante, descolorar>descolorante). Não foram encontradas bases formadas por circunfixação.

O sufixo anexa-se maioritariamente a verbos transitivos. Seguemse os verbos inacusativos e, por último, os inergativos. Como exemplos de bases transitivas podem mencionar-se verbos indicadores de desempenho (atacar>atacante, celebrar>celebrante, dominar $>$ dominante, licitar $>$ licitante), causativos (intrigar $>$ intrigante, judaizar>judaizante, justificar>justificante, moralizar>moralizante, reconfortar $>$ reconfortante) e declarativos e de atos de fala (citar $>$ citante, contestar $>$ contestante, criticar $>$ criticante). São bases inacusativas, por exemplo, os verbos de existência/estado (equivaler>equivalente, expectar>expectante), mover-se em direção específica (confluir>confluente, transcender>transcendente), incoativos (crescer>crescente, minguar>minguante), aparecimento (incidir $>$ incidente, resultar>resultante). São bases inergativas os verbos indicadores de desempenho (militar>militante), de modo de moção (cavalgar $>$ cavalgante, rodar $>$ rodante, rodopiar $>$ rodopiante), de emis- 
são de som (estridular>estridulante, soar>soante), de emissão de luz (brilhar>brilhante) e de emissão de substância (espumar>espumante), como se descreve circunstanciadamente em Rodrigues (2008).

Os adjetivos em - nt (e) designam uma propriedade intrínseca assente na relação entre os indivíduos que a detêm e o evento designado pela base. Não se encontram semantismos conectáveis com argumentos internos de verbos transitivos, mas apenas com argumentos internos de verbos inacusativos e com argumentos externos de verbos transitivos e inergativos. Existe uma relação entre os semantismos e o argumento que ocupa sintaticamente a função de sujeito do verbo base. Contudo, essa ligação é semântica. Esta relação deve-se ao facto de historicamente o sufixo - nt (e) ter origem num morfema flexional do particípio do presente (Nunes [1919] 1989: 303-304 e Said Ali 1964: 146). Esta função é ainda visível no português atual em expressões como homem temente a Deus, homem amante de um bom vinho.

O traço do sufixo é [que tem a propriedade de V], pelo que um astro brilhante 'tem a propriedade de brilhar', um tiro fulminante 'tem a propriedade de fulminar', um material absorvente 'tem a propriedade de absorver'. Este traço explica que, quando um verbo apresenta alternância inacusativa, o produto mostra a significação correspondente à inacusativa, desde que o sujeito desta seja detentor de 'propriedade de V'. Por exemplo, verbos como minguar dispõem de uma construção transitiva, como em a baixa temperatura minguou a massa, e de uma construção inacusativa (a massa minguou). O produto minguante 'aquilo que mingua' corresponde ao sujeito da construção inacusativa. Tal deve-se ao facto de ser este a deter a propriedade associada ao evento designado pelo verbo.

No caso de verbos transitivos com alternância inacusativa como corar, relaxar não se verifica o mesmo. Corante e relaxante correspondem ao argumento externo da construção transitiva, dado que são estes que têm 'a propriedade de V': a tinta corou o tecido/ o 
tecido corou; a tinta corante, mas não *o tecido corante. Este comportamento distinto mostra que o sufixo se anexa a componentes semânticos da base (o elemento susceptível de possuir a 'propriedade de V') e não a constituintes formatados sintaticamente, ainda que possam ter correspondência com estes.

Os componentes semânticos escolhidos por este sufixo prendem-se com o elemento mais proeminente da estrutura léxico-conceptual da base. Numa hierarquia temática (Levin \& Rappaport Hovav 2005: 154-185; Alsina 1996: 38-43), os papéis mais proeminentes são aqueles que possuem traços semânticos de Proto-Agente. Seguindo Dowty (1991), o Proto-Agente é caraterizado por ser 'causativo', 'controlador', 'ativo' e 'sensivo'. Num verbo que seja base de um adjetivo em - nt (e), o elemento da estrutura conceptual que mais traços de Proto-Agente contiver é aquele que mais compatível se revela com o semantismo do derivado deste sufixo. Tenha-se em conta que os traços não funcionam em blocos, mas em feixes, pelo que alguns poderão estar ou não presentes num dado papel-temático.

A distinção entre os adjetivos construídos com o sufixo -dor e com o sufixo $-n t(e)$ é saliente na significação dos produtos. Um material absorvente tem a 'propriedade de absorver', ou seja, possui caraterísticas intrínsecas que lhe conferem essa propriedade. Exemplos como falante e falador, desmagnetizante e desmagnetizador, tratante e tratador ilustram a diferença. Um indivíduo falador é um indivíduo 'que fala muito'; um indivíduo falante 'tem a propriedade de V'. Um produto desmagnetizante 'tem a propriedade de desmagnetizar'; um aparelho desmagnetizador 'tem a função de desmagnetizar'. O significado de tratante passa de 'pessoa que trata, negoceia' a 'pessoa que faz negócios com ardil' e daí a 'pessoa que age ardilosamente': em suma, 'pessoa que tem a propriedade de'. Um indivíduo tratador 'tem a função de V' e não a 'propriedade'. 
O evento depende da propriedade do indivíduo e não do indivíduo que, por esse facto, é muitas vezes não controlador do evento. Como tal, os produtos em - nt (e) mostram extensões de significado em direção a 'passivo', embora este semantismo não seja comum a todos os produtos.

$\mathrm{O}$ traço [que tem a propriedade de] explica a grande quantidade de adjetivos em - nt(e), e também de nomes (cf. cap. 2: 2.4.2.7.), que qualificam agentes químicos de acordo com as propriedades dos mesmos, como absorvente, adoçante, adstringente, coagulante, diluente, entre outros.

\subsubsection{Adjetivos sufixados em - $\tilde{a} o$}

A forma da base verbal a que -ão se anexa é a do radical (responder $>$ respondão). No feminino, o sufixo adjetival toma a forma -ona.

O sufixo - ão anexa-se a bases verbais preferencialmente não eruditas e com as seguintes estruturas morfológicas: (i) bases simples não derivadas (aldrabar>aldrabão, chorar $>$ chorão, trotar>trotão); (ii) bases simples conversas (martelar $>$ martelão, marrar>marrão, sujar>sujão); (iii) bases complexas não derivadas (demandar>demandão, resmungar $>$ resmungão); (iv) bases complexas derivadas por prefixação (desgarrar $>$ desgarrão, esgarrar>esgarrão, refilar $>$ refilão, remexer $>$ remexão) e por sufixação (carrejar $>$ carrejão, corricar>corricão, guerrear>guerreão, pedinchar>pedinchão). Não se encontraram bases circunfixadas para estes produtos.

$\mathrm{Na}$ formação de adjetivos, o sufixo -ão anexa-se a bases transitivas e inergativas. Entre as bases transitivas encontram-se verbos indicadores de desempenho (lamber $>$ lambão, mandar $>$ mandão, papar>papão), causativos (remendar>remendão), declarativos e atos de fala (perguntar>perguntão, responder>respondão), de pedir (pedinchar>pedinchão), entre outros. Nas bases inergativas encontram- 
-se verbos de emissão de som (palrar>palrão, relinchar>relinchão, roncar $>$ roncão), de desempenho (brincar $>$ brincão, bulhar $>$ bulhão, mangar>mangão), de modo de moção (gingar> gingão, pinchar> pinchão), declarativos e atos de fala (ralhar>ralhão, refilar $>$ refilão). Não se encontraram verbos inacusativos como bases destes produtos.

A significação desenvolvida por estes produtos é de 'causa/ agente', ou seja, de 'instigador de um evento', quer se trate de um evento formatado através de um verbo transitivo, quer se trate de um evento enformado por um verbo intransitivo inergativo. No primeiro caso, o 'instigador do evento' coincidirá com uma 'causa externa' que é responsável pela alteração do estado de coisas num objeto (e. g. escrever, cozer). No segundo caso, o 'instigador' coincide com uma 'causa interna' que desencadeia um evento que não alcança um objeto externo a esse instigador (e. g. tossir, trotar).

O sufixo -ão permite a construção de adjetivos em que se destaca uma avaliação do indivíduo tendo em conta o caráter frequente e intenso com que efetua o evento designado pelo verbo base. Um indivíduo resmungão é um indivíduo 'que resmunga frequente e intensamente'; uma criança chorona é uma criança 'que chora frequente e intensamente'.

Os adjetivos deverbais em - $\widetilde{a} o$ funcionam na sua maioria como atributos de seres animados, humanos ou não. São escassos os adjetivos em -ão que servem para qualificar indivíduos não animados. Encontraram-se, no entanto, esgarrão, desgarrão (ambos referentes a vento) e queimão (referente a pimento).

Quanto aos adjetivos qualificadores de animais, surgem, por exemplo, relinchão (cavalo 'que relincha muito'), trotão (cavalo 'que trota muito/bem'), turrão (animal 'que turra ('marra') muito'), zornão (burro zornão 'que zorna ('zurra'). Trata-se sobretudo de adjetivos que indiciam a emissão de som ou o modo de locomoção ou de movimento do indivíduo. 
Quanto aos adjetivos qualificadores de humanos, existem exemplos como bailão ('que baila muito'), berrão ('que berra muito'), chorão ('que chora muito'), pedinchão ('que pedincha muito'), ralhão ('que ralha muito'), resmungão ('que resmunga muito'), rezão ('que reza muito'), entre outros. Também nestes se destacam os adjetivos que indicam a emissão de som, o modo de locomoção e comportamental do indivíduo que, por serem frequentes e intensos neste, o tipificam.

\subsubsection{Adjetivos sufixados em -tóri(o/a)}

Muitos lexemas que apresentam este sufixo correspondem a adjetivos latinos. Contudo, o sufixo permite formar lexemas em português (cf. cap. 2: 2.4.2.11), preferindo bases de caráter erudito.

As bases, quanto à sua estrutura morfológica, são dos seguintes tipos: (i) bases simples não derivadas (abonar>abonatório, negar>negatório, obrigar>obrigatório); (ii) bases simples derivadas (verbos conversos) (circular $>$ circulatório, seringar $>$ seringatório); (iii) bases complexas não derivadas (exclamar>exclamatório, exonerar>exoneratório, perturbar>perturbatório, reprovar $>$ reprovatório ); (iv) bases complexas derivadas por sufixação (justificar>justificatório, purificar> purificatório) e por prefixação (reconciliar>reconciliatório, transmigrar>transmigratório).

O sufixo anexa-se a bases na sua maioria transitivas, depois inergativas e por último inacusativas. No âmbito das bases transitivas encontram-se muitos verbos indicadores de desempenho (congratular $>$ congratulatório, notificar $>$ notificatório, recriminar $>$ recriminatório), causativos (agravar>agravatório, purificar $>$ purificatório, secar $>$ secatório), declarativos e de atos de fala (abjurar>abjuratório, admoestar>admoestatório, 
apelar>apelatório, convocar>convocatório). No âmbito das bases inergativas, encontram-se verbos de modo de moção (oscilar $>$ oscilatório, perambular $>$ perambulatório, vacilar $>$ vacilatório) e de emissão de substância (defecar $>$ defecatório, exsudar>exsudatório, transpirar $>$ transpiratório). Como bases inacusativas, que são escassas, registam-se verbos de movimento em direção específica (emigrar>emigratório, imigrar>imigratório).

Os adjetivos em -tóri- não qualificam seres animados, de tipo humano ou não (*homem abjuratório, *homem bajulatório, *homem blasfematório, *homem condenatório). Podem, no entanto, qualificar atitudes ou atos de seres humanos, como ato abjuratório, ato bajulatório, ato blasfematório, ato condenatório, entre outros.

Para além de designarem atributos de atos/atitudes humanos, muitas vezes de caráter jurídico (ato adjudicatório, declinatório), são também numerosos os adjetivos em -tóri- que servem para qualificar substâncias químicas (substância vesicatória, transpiratória, expurgatória).

Existem produtos em -tóri- de 'causa' com correspondência com os argumentos externos de verbos transitivos e inergativos, como circulatório, giratório, ondulatório, oscilatório, purificatório, refrigeratório.

Há também adjetivos correspondentes ao argumento interno de verbos inacusativos (emigratório, escapatório) e transitivos (alienatório, aspiratório, transplantatório). Tal facto mostra que o sufixo não se correlaciona univocamente com funções sintáticas, nem com formatações argumentais. $\mathrm{O}$ adjetivo transplantatório comprova-o, pois designa 'causa' 'que possibilita a transplantação' e em simultâneo 'objeto' 'que pode ser transplantado'.

A semântica comum a estes produtos é parafraseada por 'relativo a/próprio de'.

Os produtos adjetivais deste sufixo detêm caráter técnico e erudito. 


\subsubsection{Adjetivos sufixados em -óri(o/a)}

O sufixo anexa-se ao radical da base verbal (relamber>relambório) e forma adjetivos que significam 'que é relativo a/próprio de'.

Os adjetivos em -óri- têm notória correspondência com lexemas latinos, como também acontece com os nomes em -óri- (2.4.2.12.) e em -tóri- (2.4.2.11.). Apenas relambório 'preguiçoso; reles; insípido' não apresenta essa correspondência e possui um caráter não erudito. Os restantes caraterizam-se por caráter erudito.

As bases são morfologicamente: (i) bases complexas não derivadas (expulsar>expulsório); (ii) bases simples não derivadas (executar>executório, ustir>ustório, vomitar >vomitório); (iii) bases complexas derivadas (relamber>relambório); (iv) bases simples conversas (transitar>transitório).

O sufixo combina-se com bases transitivas de desempenho (executar>executório, requisitar>requisitório, vomitar>vomitório) e causativas (ustir>ustório) e com bases inacusativas de movimento (transitar>transitório).

O único produto adjetival em -óri- aplicável a seres humanos encontrado é relambório 'preguiçoso'. Os restantes aplicam-se a atos (ato requisitório, executório) e a substâncias (substância vomitória, ustória). Tal como os demais adjetivos em -tóri-, estes significam também 'que é relativo a/próprio de'.

\subsubsection{Adjetivos sufixados em $-\operatorname{eir}(o / a)$}

O sufixo anexa-se ao radical da base verbal (palrar>palreiro) e forma adjetivos como beijoqueiro, coscuvilbeiro, debiqueiro, galreiro, lambisqueiro.

Sob o ponto de vista morfológico, as bases são: (i) bases simples não derivadas (errar>erreiro, gear>geeiro, galgar>galgueiro); 
(ii) bases simples derivadas (cumprimentar>cumprimenteiro); (iii) bases complexas sufixadas corricar $>$ corriqueiro, lambarar $>$ lambareiro). Não se encontram bases complexas não derivadas, assim como derivadas com sufixos de caráter erudito.

$\mathrm{Na}$ base destes adjetivos há sobretudo verbos inergativos e transitivos. Dos verbos inergativos destacam-se os que designam desempenho (choramingar>choramingueiro), atos de fala (palrar $>$ palreiro, rezingar $>$ rezingueiro, taramelar $>$ tarameleiro), modo de moção (caminhar>caminheiro, trotar>troteiro). Dos verbos transitivos destacam-se também os que designam desempenho (ceifar $>$ ceifeiro, costurar $>$ costureiro, lamber $>$ lambeiro). Encontrouse um verbo inacusativo (vergar>vergueiro $)^{45}$.

Os adjetivos em -eir- apresentam significações de causa e possuem muitas vezes uma carga avaliativa a que não é alheio o próprio significado do verbo base. Produtos como beijoqueiro, coscuvilheiro, debiqueiro, galreiro, lambisqueiro, palreiro representam qualidades de indivíduos que se destacam pela frequência/intensidade com que efetuam o evento designado pela base.

\subsubsection{Adjetivos sufixados em - os $(o / a)$}

O sufixo -os $(o / a)$ anexa-se ao radical das bases (queixar>queixoso) e forma adjetivos (bumilhoso, imaginoso, necessitoso) que denotam sobretudo qualidades de tipo psicológico ('qualidade daquele que V'). Trata-se de um sufixo muito comum na formação de adjetivos denominais (cf. cap. 3: 3.1.3.2). Contudo, formas como bumilhoso,

45 Em Bluteau (1712-1728) o verbo vergar encontra-se registado apenas na construção intransitiva. Como referido por Chierchia (1989), os verbos inacusativos sem construção transitiva original tendencialmente desenvolvem essa construção, manifestando a inclusão de uma causa externa que, na forma inacusativa, não é inerente ao verbo. Por esse motivo, no português contemporâneo o verbo exibe alternância transitiva/intransitiva. 
imaginoso, necessitoso, para as quais não estão disponíveis bases nominais, mostram que também se agrega a verbos. Adjetivos como elogioso, enredoso, zeloso, por exemplo, podem ser formados com base no radical verbal de elogiar, enredar, zelar ou no radical nominal de elogio, enredo, zelo (cf. secção 1.6.3. do cap. 1).

Morfologicamente, as bases verbais a que -os- se pode anexar são: (i) bases simples não derivadas (aceitar>aceitoso, chorar $>$ choroso, humilhar>humilhoso); (ii) bases simples conversas (babar $>$ baboso, cobiçar $>$ cobiçoso, estimular $>$ estimuloso); (iii) bases complexas derivadas por prefixação (afadigar $>$ afadigoso, afrontar $>$ afrontoso, agravar>agravoso, embaraçar>embaraçoso, enfastiar>enfastioso, enredar>enredoso). Não se encontraram bases com afixos eruditos.

No que diz respeito aos tipos sintático-semânticos das bases, este prefixo tem preferência por bases verbais transitivas de sujeito-estímulo com experienciador-objeto, como afadigar>afadigoso, aliviar>alivioso, assustar>assustoso, injuriar $>$ injurioso, mas também de experienciador-sujeito (recear $>$ receoso, suspeitar $>$ suspeitoso) e inergativos de emissão de som (chorar $>$ choroso, ciciar $>$ cicioso, estrepitar $>$ estrepitoso, murmurar $>$ murmuroso, suspirar $>$ suspiroso). Os verbos inacusativos são raros, como murchar> murchoso. Repare-se que, na sua maioria, os verbos estão relacionados genolexicalmente com um nome (injúria, inveja, lástima, zelo), de que também pode advir o adjetivo em -os-, que designa um 'estado psicológico'.

Os produtos adjetivais designam 'qualidade daquele que V', ou seja, possuem uma significação de 'causa': assombroso 'que assombra', enganoso 'que engana', agravoso 'que agrava', assustoso 'que assusta'. Existem alguns adjetivos com base em verbos transitivos com significação de 'objeto', como aceitoso 'que é de aceitar', lastimoso 'que é de lastimar'. Verbos inacusativos como murchar dão origem à significação 'que V' correspondente ao argumento interno da base (murchoso 'que murcha'). 


\subsubsection{Adjetivos sufixados em $-\operatorname{tiv}(o / a)$}

Muitos dos adjetivos portadores deste sufixo têm correspondência com formas latinas que lhes podem servir de étimo; mas alguns adjetivos em -tiv- ${ }^{46}$, como desenjoativo, despertativo, refrigerativo, não se encontram nessa situação, pois não existem as formas latinas de que possam provir. Os adjetivos designam causa: curativo equivale a 'que cura', desenjoativo a 'que desenjoa', fugitivo 'que foge', qualificativo 'que qualifica'.

O sufixo anexa-se à forma do tema da base verbal (preparar> preparativo).

Morfologicamente, as bases verbais a que -tiv-se pode anexar são: (i) bases simples não derivadas (curar>curativo, fugir $>$ fugitivo; sedar>sedativo); (ii) bases complexas não derivadas (indicar $>$ indicativo, preparar>preparativo, refrigerar > refrigerativo); (iii) bases complexas derivadas por prefixação (desenjoar>desenjoativo).

No que diz respeito aos tipos sintático-semânticos das bases, o sufixo anexa-se a bases transitivas, especialmente causativas (aumentar>aumentativo, curar>curativo, desenjoar $>$ desenjoativo, preservar $>$ preservativo). Encontrou-se uma base intransitiva (fugir>fugitivo).

\subsubsection{Adjetivos sufixados em -iv $(o / a)$}

As escassas formas em -iv- apresentam as mesmas significações presentes nos adjetivos em -tiv-. Mais uma vez, estamos perante adjetivos com formato latino. Contudo, a existência de processivo, sem contraparte em latim, prevê a possibilidade de formação de adjetivos com sufixo sob a forma de -iv-em português. Abrasivo,

46 Para a formatação -tivo/-ivo veja-se a secção 2.4.2.20 e Nunes (s/d: 371). 
abortivo, vomitivo são os restantes adjetivos encontrados, que todavia têm contraparte latina. Em vomitivo e abortivo a causa não coincide com nenhum argumento da base verbal. Vomitivo designa 'que faz vomitar' e não 'que vomita'; e abortivo 'que faz abortar' e não 'que aborta'.

\subsubsection{Adjetivos sufixados em $-\operatorname{diç}(o / a)$}

Este sufixo anexa-se ao tema do verbo (espantar>espantadiço). Alguns adjetivos em -diç- parecem poder ser analisados como portadores do sufixo -iç- que se anexaria ao radical do particípio passado, como em espantado>espantadiço. Três ordens de razões fazem-nos preferir a hipótese de se tratar de derivados em -diç-. A primeira tem que ver com o facto de existirem muito poucos adjetivos deverbais em -diç- em comparação com a quantidade de adjetivos conversos do particípio e com a agramaticalidade que resulta da sufixação em -iç- em formas como *cozinhadiço, *estudadiço, *solidificadiço. Em segundo lugar, existem exemplos como namoradiço, em que o significado do produto não coincide com o referente do particípio namorado. Em namorado o significado é de 'que é Vdo', enquanto em namoradiço o significado é de 'que V'. O mesmo ocorre em chovediço. O particípio passado de chover não é convertível em adjetivo, pelo facto de se tratar de um verbo sem argumento interno. Em todo o caso, o produto chovediço designa 'que ameaça chuva' e não 'que é Vdo', pelo que não está conforme ao significado do particípio passado. Em terceiro lugar, os produtos em apreço anexam-se, na sua maioria, ao tema do presente (chover>chovediço, correr $>$ corrediço, esquecer>esquecediço) e não ao radical do particípio chovido/ chovediço, corrido/corrediço, esquecido/esquecediço), como se observa pela configuração da vogal temática. 
Os produtos nascidiço e perdidiço, que parecem contrariar o anteriormente postulado, coexistem com as formas nascediço e perdediço. A favor da hipótese -iç- encontram-se ainda os produtos deverbais esgueiriço, tolhiço e o denominal outoniço. Estes exemplos parecem apontar para uma hesitação na própria delimitação do sufixo no seu uso. Pelo facto de serem em maior número os exemplos que apontam para a configuração em -diç-, opta-se aqui por esta hipótese ${ }^{47}$.

Os tipos de bases morfológicas, preferencialmente não eruditas, são:

(i) bases simples não derivadas (achacar > achacadiço, nascer $>$ nascediço, perder $>$ perdediço);

(ii) bases simples derivadas (verbos conversos) (contentar $>$ contentadiço);

(iii) bases complexas não derivadas (intrometer $>$ intrometediço);

(iv) bases complexas derivadas por prefixação (abafar>abafadiço, acomodar $>$ acomodadiço, afrontar $>$ afrontadiço, desmanchar $>$ desmanchadiço, desmoronar $>$ desmoronadiço, enfastiar $>$ enfastiadiço, enojar>enojadiço, escaldar>escaldadiço, esquentar>esquentadiço).

A única base complexa não derivada encontrada foi intrometer> intrometediço.

No que diz respeito aos tipos sintático-semânticos das bases, o sufixo prefere bases transitivas causativas (abalar>abaladiço, achacar $>$ achacadiço, afogar $>$ afogadiço, desmanchar $>$ desmanchadiço, escaldar>escaldadiço, espantar>espantadiço, quebrar> quebradiço) e

47 A ambiguidade formal não deve ser estranhada. No percurso do latim para o português, muitos são os sufixos que naquela língua se anexam ao radical do supino e que, em português, se autonomizam criando uma unidade com o segmento daquele. A este facto não deve ser alheia a formatação de sílaba com ataque com esse segmento do supino. Apontem-se os casos de -dura, -deiro, -dor, -douro, entre outros. 
inacusativas (cair $>$ caidiço, embarcar>embarcadiço, enjoar $>$ enjoadiço ${ }^{48}$, escapar $>$ escapadiço, morrer $>$ morrediço, nascer $>$ nascediço, sumir $>$ sumidiço). As bases transitivas e inacusativas designam, na sua maioria, eventos negativos (enganar>enganadiço, enojar>enojadiço, perder> perdediço, quebrar $>$ quebradiço). Ocorrem ainda as bases inergativas chover $>$ chovediço e namorar $>$ namoradiço.

Os produtos formados a partir de bases inacusativas e transitivas têm uma significação de 'objeto' 'que é Vdo', a que acresce o matiz de 'facilmente'. Assim, unhas quebradiças 'quebram-se facilmente', homem enganadiço 'engana-se facilmente', pessoa irritadiça 'irrita-se facilmente'. Estes adjetivos designam 'caraterísticas intrínsecas' que não estão dependentes de causas externas, assim se explicando que sejam parafraseáveis pela construção de voz média.

O contributo semântico do sufixo é bem visível em exemplos como chovediço 'que ameaça chuva' e namoradiço 'que namora muito'. Apesar de se tratar de duas bases sem argumento interno ${ }^{49}$, o sufixo desenvolve significações de 'causa', 'que V', mantendo o matiz de 'facilmente'.

\subsubsection{Adjetivos sufixados em $-d i(o / a)$}

Este sufixo anexa-se ao tema do presente da base verbal (chover>chovedio) e prefere bases não eruditas. As bases morfológicas a que se adjunge este sufixo são: (i) bases simples não derivadas (chover $>$ chovedio, lavrar>lavradio, levar>levadio); (ii) bases complexas não derivadas (escorregar>escorregadio, emprestar>emprestadio).

48 O verbo enjoar é referido em Bluteau (1712-1728) apenas na construção intransitiva. A construção transitiva é posterior, manifestando a causa externa que não cabe na construção inacusativa (cf. Chierchia 2004).

${ }^{49}$ A construção do verbo namorar que serve de base ao produto namoradiço é a inergativa (O João namora muito) e não a transitiva ( $O$ João namorou a Maria.). 
No que diz respeito aos tipos sintático-semânticos das bases, o sufixo anexa-se a bases transitivas (emprestar>emprestadio, lavar $>$ lavradio, levar $>$ levadio, salgar $>$ salgadio), inacusativas (fugir $>$ fugidio, valer $>$ valedio ${ }^{50}$ ) e inergativas (chover $>$ chovedio, errar>erradio, luzir>luzidio, reinar $>$ reinadio).

Os produtos de bases transitivas designam 'objeto' 'que tem caraterísticas/condições para ser Vdo' (lavradio, levadio, salgadio, emprestadio). Os produtos de bases inacusativas designam 'que tem condições/caraterísticas para V' (fugidio, valedio). Os produtos de bases inergativas significam 'causa' 'que $\mathrm{V}$ intensamente' (reinadio, luzidio).

\subsubsection{Adjetivos sufixados em -ist(a)}

O sufixo, invariável quanto ao género, anexa-se à forma do radical da base verbal (relaxar>relaxista).

As bases verbais caraterizam-se morfologicamente por terem as seguintes estruturas: (i) bases simples não derivadas (chupar>chupista, troçar>trocista); (ii) bases complexas não derivadas (consumir $>$ consumista, relaxar $>$ relaxista); (iii) bases complexas derivadas por prefixação (transformar>transformista); (iv) bases simples derivadas (burlar>burlista, calcular $>$ calculista).

As bases com que se combina este sufixo são transitivas de desempenho (consumir>consumista, calcular $>$ calculista, burlar $>$ burlista). Encontrou-se um adjetivo em -ist (a) com base num verbo inacusativo (relaxar>relaxista).

O sufixo -ist(a) não apresenta produtividade considerável na anexação a bases verbais. Contudo, os adjetivos deverbais analisados têm

50 O verbo valer é classificável como inacusativo, seguindo Levin \& Rappaport Hovav (1995), devido a não incluir argumentos com preenchimento semântico de 'causa'. 
sentido de 'causa'. A significação de consumista é de 'que consome muito', a de trocista 'que troça muito'. A significação de 'causa' surge com o matiz de 'intensidade com que se efetua V'.

\subsubsection{Adjetivos sufixados em -az}

O sufixo, de escassa produtividade, anexa-se a bases verbais na forma do radical (morder>mordaz). As bases apresentam as seguintes caraterísticas morfológicas: (i) bases simples não derivadas (roer $>$ roaz, tragar $>$ tragaz, lamber $>$ lambaz) e (ii) bases complexas derivadas por prefixação (remorder>remordaz). As bases verbais são transitivas de desempenho (morder>mordaz, tragar $>$ tragaz, remorder $>$ remordaz, pugnar>pugnaz). Encontrou-se uma base inergativa de emissão de som (estourar>estouraz) e uma inacusativa (folgar> folgaz).

Os produtos em -az designam 'causa'. Assim, tragaz designa 'que traga', pugnaz 'que pugna', folgaz 'que folga'.

\subsubsection{Adjetivos sufixados em -vel}

O sufixo -vel é um sufixo extremamente produtivo e anexa-se à base verbal no formato do tema do particípio (acender/ acendido>acendivel; apetecer/apetecido>apetecível).

As bases, eruditas e não eruditas, distribuem-se pelas seguintes classes de estruturas morfológicas: (i) bases simples não derivadas: papar>papável, palpar>palpável, pagar>pagável; (ii) bases simples derivadas (conversas): acidar>acidável, acidentar>acidentável; (iii) bases complexas derivadas por prefixação (abafar $>$ abafável, desfigurar $>$ desfigurável, enumerar>enumerável, esgotar $>$ esgotável); sufixação (acidificar>acidificável, fertilizar>fertilizável, 
fluidificar>fluidificável, harmonizar>harmonizável) e circunfixação (escurecer>escurecível); (iv) bases complexas não derivadas (abjudicar>abjudicável, abdicar>abdicável, auferir>auferível).

A maioria das bases a que o sufixo se junta é de tipo transitivo (apagar>apagável, dominar>dominável, engolir>engolível, representar $>$ representável). Encontram-se também bases inacusativas (nascer $>$ nascível, variar $>$ variável ${ }^{51}$ ). Não se encontram bases inergativas (correr $>$ *corrível, palrar $>$ *palrável, trotar $>$ *trotável). Repare-se que é possível a formação de um adjetivo em -vel se o verbo apresentar possibilidade de construção transitiva (e.g. O João galopa o caminho. /Este caminho é galopável. vs. O cavalo galopa. /*O cavalo é galopável).

Estes produtos têm o significado de 'objeto que pode ser Vdo' ou 'que V'.

No caso de o argumento externo da base transitiva representar uma causa externa e o argumento interno um Tema (cf. Levin \& Rappaport Hovav 1995), o adjetivo corresponde, na sua significação, ao argumento interno. É o caso de transformável, solidificável, acidificável, aglutinável, etc. Assim, estes produtos são parafraseáveis por 'que pode ser Vdo'.

Há também algumas bases inacusativas (nascer, perecer, perdurar) e ainda bases com dois argumentos (cf. durar, casar). Nestas, contudo, não existe uma relação de causatividade entre ambos (Levin \& Rappaport Hovav 1995: 120). Nestes casos, a significação do adjetivo em - vel corresponde ao argumento interno que ocupa sintaticamente a função de sujeito: casável 'que pode/está em condições de casar', durável 'que pode/está em condições de durar', nascível 'que pode/está em condições de nascer', perecível 'que

51 Diacronicamente, a construção transitiva de variar é posterior à construção inacusativa (cf. Bluteau 1712-1728). Veja-se Chierchia (2004) para o desenvolvimento da construção transitiva. 
pode/ está em condições de perecer', perdurável 'que pode/está em condições de perdurar'.

Aparentemente, os produtos em -vel correspondem ao argumento interno da base verbal. De facto, de alguns verbos psicológicos, como assustar, aterrorizar, entusiasmar, derivam-se adjetivos em -vel cujo significado corresponde ao argumento interno. Entusiasmável, assustável, aterrorizável significam 'que pode /está em condições de ser Vdo'. Os produtos em -vel de verbos como temer, recear, abominar também desenvolvem significação correspondente ao argumento interno. Repare-se que nos verbos entusiasmar, assustar, aterrorizar, o argumento externo corresponde a um Estímulo e o argumento interno a um Experienciador (e. g. O fantasma aterrorizou o Mário. A ideia entusiasmou o Pedro.). Nos verbos temer, recear, abominar, o Experienciador ocupa o argumento externo, enquanto o Estímulo ocupa o argumento interno (e. $g$. O Mário receia o fantasma./ O Rui abomina chocolate.). Esta variação deve-se ao caráter semântico do elemento não Experienciador. De acordo com Levin \& Rappaport Hovav (2005: 159-160), se o não Experienciador possuir um caráter de causa/instigação do evento, este ocupará o lugar de argumento externo. Isto ocorre nos verbos entusiasmar, assustar, aterrorizar. Nos verbos temer, recear, abominar, o não Experienciador é passivo, pelo que o argumento externo é ocupado pelo Experienciador.

Observemos agora produtos como agradável, aprazível, apetecível cujos significados apresentam correspondência com o argumento que ocupa o lugar de sujeito sintático (O João agrada à Maria.) O João é agradável. A viagem apraz à Maria./ A viagem é aprazível. o gelado apetece-lhe. / O gelado é apetecível.). Os verbos agradar, aprazer e apetecer possuem o Estímulo na função sintática de sujeito. Contudo, não se comportam como entusiasmar, assustar, aterrorizar. Nestes, também o sujeito contém o Estímulo (O fantasma aterrorizou o Mário.). No entanto, enquanto em aterrorizar o 
Estímulo possui um caráter de causatividade, em agradar, aprazer e apetecer, o Estímulo não possui caráter de causatividade.

Este facto verifica-se na formatação do objeto como indireto, i.e. na forma dativa. Em termos semânticos, esta formatação indicia que o sujeito não possui causatividade suficiente para a afetação direta do objeto. Neste sentido, não é possível uma construção do tipo *A Ana agrada ao Mário voluntariamente; mas é possível A Ana aterroriza o Mário voluntariamente. Ou seja, nos dois tipos de verbos o sujeito é o Estímulo. No entanto, nos verbos do tipo aterrorizar o Estímulo é causativo; nos verbos como agradar, o Estímulo não é causativo.

O objeto indireto de agradar, aprazer, apetecer, apesar de sofrer essa formatação morfossintática, detém mais caráter de [+ ativo] do que o sujeito. Isto é visível em construções com gerúndio, em que o elemento dativo (objeto indireto) é que é correferencial com o sujeito do gerúndio (Levin \& Rappaport Hovav 2005: 30):

(1) a. Tendo visto o gelado, este apeteceu-lhe. b. "Tendo sido visto o gelado, este apeteceu-lhe.

O mesmo não se verifica em relação aos outros dois tipos de verbos psicológicos. Nestes, o elemento que é correferencial com o gerúndio é o sujeito do verbo psicológico, e não o objeto:

(2) a. Tendo visto o monstro, o João temeu-o.

b. "Tendo sido visto o monstro, o João temeu-o.

c. Tendo aparecido o monstro, este aterrorizou o Mário.

d. *Tendo visto o monstro, este aterrorizou o Mário.

A comparação dos produtos dos três tipos de verbos psicológicos mostra que o sufixo -vel formata o significado relacionado com o argumento com caráter mais passivo. Esse argumento corresponde ao argumento que ocupa a função de sujeito nos verbos 
psicológicos com dativo, como agradar, e ao argumento interno de verbos psicológicos de sujeito-objeto direto, independentemente de o objeto ser o Estímulo ou o Experienciador, na medida em que ambos correspondem ao elemento menos [causativo]. É interessante o caso de aborrecível no significado de 'que causa aborrecimento'. Neste caso, a base verbal é a do verbo aborrecer na construção de Experienciador-sujeito. Assim, este filme é aborrecível corresponde ao objeto de O João aborreceu o filme. Esta construção não é hoje muito utilizada, mas explica a permanência do significado de aborrecível.

Assim, -vel formata o elemento menos proeminente da estrutura léxico-conceptual da base. Recorde-se que - nt (e) formata o elemento mais proeminente, sendo este definido através do caráter de agentividade (cf. cap. 3: 3.3.4).

\subsubsection{Adjetivos sufixados em -ent $(o / a)$}

Este sufixo anexa-se ao radical da base verbal (resmungar> resmunguento), mas não a bases verbais eruditas.

As bases a que se anexa têm as seguintes estruturas morfológicas: (i) bases simples não derivadas (rosnar>rosnento, passar>passento, ofegar>ofeguento); (ii) bases complexas derivadas por processos avaliativos (peganhar>peganhento, tossicar>tossiquento, tremelicar>tremeliquento, chorincar>chorinquento) e não avaliativos de prefixação (embirrar>embirrento).

As bases verbais destes adjetivos são dominantemente inergativas. Estas são na sua maioria de emissão de som (farfalhar> farfalbento, grulhar>grulhento, resmungar>resmunguento, rosnar>rosnento, tossicar>tossiquento). Há algumas bases transitivas (arreliar $>$ arreliento, passar $>$ passento) e inacusativas (languir> languinhento). 
O sufixo aporta uma significação de 'causa' 'que V'. No entanto, passento ('diz-se das substâncias que um líquido atravessa facilmente; hidrófilo') equivale ao semantismo de 'objeto'.

Muitas das bases verbais são avaliativas e a significação do adjetivo é tendencialmente pejorativa. Assim, peganhento significa 'que se peganha de forma desagradável', ofeguento 'que ofega de forma desagradável'. Noutros casos, como em tossiquento 'que tossica frequentemente' e resmunguento 'que resmunga frequentemente', o timbre avaliativo denota-se no semantismo de 'frequente' dos produtos.

\subsubsection{Quadro final}

No quadro seguinte explicitam-se as relações entre os sufixos que formam adjetivos deverbais e o tipo de significação dos seus produtos.

\begin{tabular}{|c|c|c|}
\hline \multirow{2}{*}{$\begin{array}{l}\text { Sufixos formadores } \\
\text { de adjetivos deverbais }\end{array}$} & \multicolumn{2}{|c|}{ Significações } \\
\hline & Agente/causa & Objeto \\
\hline$-\tilde{a} o$ & + & \\
\hline$-a z$ & + & \\
\hline$-\operatorname{deir}(o)$ & + & + \\
\hline$-\operatorname{diç}(o)$ & + & + \\
\hline$-d i(o)$ & + & + \\
\hline$-d o r$ & + & \\
\hline$-\operatorname{dour}(o)$ & + & + \\
\hline$-\operatorname{eir}(o)$ & + & \\
\hline$-e n t(o)$ & + & + \\
\hline$-i s t(a)$ & + & \\
\hline$-i v(o)$ & + & \\
\hline$-n t(e)$ & + & \\
\hline -óri(o) & + & \\
\hline$-o s(o)$ & + & + \\
\hline$-t i v(o)$ & + & \\
\hline -tóri(o) & + & + \\
\hline$-v e l$ & & + \\
\hline
\end{tabular}

Quadro III.8. Distribuição de significações por sufixos de formação de adjetivos deverbais 
Este quadro evidencia que existem sufixos que disponibilizam

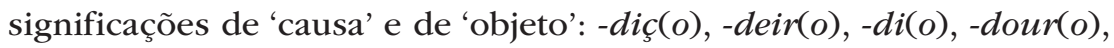
-ent(o), -óri(o), -os(o) e -tóri(o). Já os sufixos -ão, -az, -nt(e), -dor, -eir(o), -ist (a), -iv(o) e -tiv(o) apenas constroem adjetivos com significação causal. O sufixo -vel é o único sufixo que se atém a significações de 'objeto'.

Esta distribuição relaciona-se com a sensibilidade que o sufixo tem relativamente aos traços semânticos da base verbal.

No quadro seguinte sintetizam-se as relações entre estes sufixos e os tipos sintático-semânticos das bases verbais.

\begin{tabular}{|c|c|c|c|}
\hline \multirow{2}{*}{$\begin{array}{l}\text { Sufixos } \\
\text { formadores } \\
\text { de adjetivos } \\
\text { deverbais }\end{array}$} & \multicolumn{3}{|c|}{ Tipos de bases } \\
\hline & transitivas & inergativas & inacusativas \\
\hline$-\tilde{a} o$ & + & + & \\
\hline$-a z$ & + & + & + \\
\hline$-\operatorname{deir}(o)$ & + & + & + \\
\hline$-\operatorname{diç}(o)$ & + & + & + \\
\hline$-d i(o)$ & + & + & + \\
\hline -dor & + & + & + \\
\hline$-\operatorname{dour}(0)$ & + & & + \\
\hline$-\operatorname{eir}(o)$ & + & + & + \\
\hline$-\operatorname{ent}(\boldsymbol{o})$ & + & + & + \\
\hline$-i s t(a)$ & + & & + \\
\hline$-i v(o)$ & + & + & \\
\hline$-n t(e)$ & + & + & + \\
\hline -óri(o) & + & & + \\
\hline$-\operatorname{os}(\boldsymbol{o})$ & + & + & + \\
\hline$-\operatorname{tiv}(o)$ & + & & + \\
\hline -tóri(o) & + & + & + \\
\hline -vel & + & & + \\
\hline
\end{tabular}

Quadro III.9. Seleção de tipos sintático-semânticos de bases verbais por sufixos formadores de adjetivos deverbais

Este quadro salienta que a maioria dos sufixos pode anexar-se a bases transitivas, inergativas e inacusativas. Escassos sufixos mostram seletividade neste domínio. Os sufixos -vel, -tiv(o), -óri(o), -ist(a) e 
- $\operatorname{dour}(o)$ não escolhem bases inergativas. Os sufixos -iv(o) e -ão não foram encontrados com bases inacusativas. Em alguns casos, esta seleção é sensível a traços semânticos da estrutura léxico-conceptual dos verbos. Tal ocorre com - vel que, na formação do produto, se associa ao componente menos elevado da hierarquia temática do verbo e com -nte que mostra preferência pelo componente mais elevado da referida hierarquia.

A formação de adjetivos deverbais faz-se também com recurso ao processo de conversão de radicais (bajoujo), temas do presente (saranda) e particípios passados (cozido). Neste último caso, a estrutura argumental da base é determinante para a (im)possibilidade de geração de adjetivos, pois apenas verbos com argumento interno dão origem a adjetivos conversos de particípios passados.

\subsubsection{Adjetivos conversos de radical e de tema verbais}

A conversão é um processo que também dá origem a um conjunto escasso de adjetivos deverbais. Encontram-se neste domínio adjetivos como bajoujo 'que se excede em lisonjas; baboso; perdido de amores', rasca 'fraco' e pisco 'que come pouco'.

Os adjetivos formados por conversão do radical e do tema designam causa.

São formados por conversão do tema verbal os adjetivos penetra 'que entra numa festa sem ser convidado', pedincha 'que pede muito ou está sempre a pedir' e saranda 'diz-se do indivíduo vadio, vagabundo'. Estes produtos resultam da conversão do verbo, na forma de $3 .^{a}$ pessoa do singular do presente do indicativo, coincidente com a forma do tema, em adjetivo. O facto de resultarem da conversão de forma de palavra torna-os morfologicamente invariáveis quanto ao género (O João penetra / A Joana penetra conseguiu entrar na festa.). 
A ocorrência destas formas à direita de nomes ( A Ana saranda correu a cidade a pé.) e em estruturas de gradação ( $A$ Ana é muito saranda./ A Ana é mais saranda do que o irmão.) mostra que se trata de adjetivos.

\subsubsection{Adjetivos conversos do particípio passado}

Os adjetivos que resultam da conversão do particípio passado, ainda que resultantes da conversão de uma forma flexional, são aqui assinalados na medida em que a base é um verbo. Adjetivos como abafado, electrocutado, desaparafusado, nascido, desaparecido correspondem ao particípio passado do verbo que, enquanto tal, é uma forma flexional do lexema verbal. A conversão sintática do particípio passado resulta na categoria sintática de adjetivo (cf. cap. 1: 1.6.3., a propósito da conversão).

Como formas conversas do particípio passado que significam 'objeto', apenas se encontram adjetivos conversos do particípio que provêm de verbos transitivos e inacusativos. Assim, verbos inergativos não estão na origem destes adjetivos, na medida em que o único argumento que os verbos inergativos têm é o argumento externo, que não pode ocorrer em particípio absoluto (*Tossido o João...). Apenas os verbos inergativos que dispõem de alternância transitiva apresentam adjetivo converso do particípio. É este o caso de, por exemplo, galopado 'percorrido a galope', equivalente à construção transitiva $O$ João galopou $10 \mathrm{~km}$ e não à construção inergativa o cavalo galopou. Neste último caso, não é possível o particípio absoluto *Galopado o cavalo.

Observemos verbos inergativos sem alternância transitiva:

(3) a. O João ressonou.

b. *Ressonado o João, fomos passear. 
c. *O João ressonado é inteligente.

(4) a. O rapaz resmungou.

b. *Resmungado o rapaz, fomos passear.

c. *O rapaz resmungado é inteligente.

(5) a. A Ana esbracejou.

b. "Esbracejada a Ana, fomos passear.

c. *A Ana esbracejada é inteligente.

As construções (a) mostram o verbo inergativo, com um único argumento, que é externo. As construções (b) mostram uma hipotética construção de particípio absoluto, que resulta agramatical, devido ao facto de se tratar de verbos inergativos. As construções (c) apontam hipotéticos adjetivos conversos do particípio passado dos mesmos verbos, que se revelam agramaticais.

Comparemos agora as estruturas anteriores com construções transitivas:

(6) a. O João lavou os cobertores.

b. Lavados os cobertores, fomos passear.

c. Os cobertores lavados cheiram bem.

(7) a. A Rita coloriu a folha.

b. Colorida a folha, fomos passear.

c. A folha colorida era pequena.

(8) a. A Maria congelou o bolo.

b. Congelado o bolo, fomos passear.

c. O bolo congelado era horrivel.

E comparemos agora as estruturas anteriores com construções inacusativas:

(9) a. O livro despareceu.

b. Desaparecido o livro, ficámos a chorar. 
c. O livro desaparecido era do séc. XVII.

(10) a. A floresta ardeu.

b. Ardida a floresta, ficámos a chorar.

c. A floresta ardida era mágica, como todas as florestas.

(11) a. O menino chegou tarde.

b. Chegado o menino, fomos passear.

c. O menino chegado é o Rui.

A comparação destes exemplos permite concluir que apenas o particípio passado com relação com o argumento interno do verbo pode sofrer conversão para adjetivo.

Se tiver relação com o argumento interno de uma base transitiva, o adjetivo significará 'objeto' 'que é Vdo' (enunciados b). Se tiver relação com o argumento interno de uma base inacusativa, o adjetivo significará 'objeto' 'que V' (enunciados 7, 8 e 9 c).

Dado tratar-se de um processo cujo único constrangimento é de caráter argumental, não existem restrições de outra ordem à conversão destes adjetivos. Assim, qualquer tipo de base morfológica funciona para estas formações.

Os semantismos destes adjetivos possuem um caráter aspetual de $[+$ perfectivo]. 